Nigussie Haregeweyn, Poesen, J., Verstraeten, G., Govers, G., de Vente, J., Nyssen, J., Deckers, J., Moeyersons, J., 2013. Assessing the performance of a spatially-distributed soil erosion and sediment delivery model (WATEM/SEDEM) in northern Ethiopia. Land Degradation and Development, 24 (2): 188-204. http://onlinelibrary.wiley.com/doi/10.1002/ldr.1121/abstract

\title{
ASSESSING THE PERFORMANCE OF A SPATIALLY DISTRIBUTED SOIL EROSION AND SEDIMENT DELIVERY MODEL (WATEM/SEDEMENTATION) IN NORTHERN ETHIOPIA
}

\author{
N. HAREGEWEYN ${ }^{1,2 *}$, J. POESEN ${ }^{3}$, G. VERSTRAETEN ${ }^{3}$, G. GOVERS ${ }^{3}$, J. DE VENTE ${ }^{4}$, J. NYSSEN $^{5}$, \\ J. DECKERS ${ }^{6}$ AND J. MOEYERSONS ${ }^{7}$ \\ ${ }^{1}$ Arid Land Research Centre, Tottori University, 1390 Hamasaka, Tottori 680-0001, Japan \\ ${ }^{2}$ Department of Land Resources Management and Environmental Protection, Mekelle University, PO Box 231, Mekelle, Ethiopia \\ ${ }^{3}$ Division of Geography, Department of Earth and Environmental Sciences, K.U. Leuven, Celestijnenlaan 200 E, B-3001 Heverlee, Belgium \\ ${ }^{4}$ Department of Desertification and Geoecology, Estación Experimental de Zonas Áridas (EEZA-CSIC), Almeria, Spain \\ ${ }^{5}$ Department of Geography, Gent University, Krijgslaan 281 (S8), B 9000 Gent, Belgium \\ ${ }^{6}$ Division of Soil and Water Management, Department of Earth and Environmental Sciences, K.U. Leuven, Celestijnenlaan 200 E, B-3001 Heverlee, Belgium \\ ${ }^{7}$ Agriculture and Forestry Economics, Royal Museum for Central Africa, B-3080 Tervuren, Belgium \\ Received 13 February 2010; Revised 14 January 2011; Accepted 14 March 2011
}

\begin{abstract}
Most regional-scale soil erosion models are spatially lumped and hence have limited application to practical problems such as the evaluation of the spatial variability of soil erosion and sediment delivery within a catchment. Therefore, the objectives of this study were as follows: (i) to calibrate and assess the performance of a spatially distributed WATEM/SEDEM model in predicting absolute sediment yield and specific sediment yield from 12 catchments in Tigray (Ethiopia) by using two different sediment transport capacity equations (original and modified) and (ii) to assess the performance of WATEM/SEDEM for the identification of critical sediment source areas needed for targeting catchment management.

The performance of the two model versions for sediment yield was found promising for the 12 catchments. For both versions, model performance for the nine catchments with limited gully erosion was clearly better than the performance obtained when including the three catchments with significant gully erosion. Moreover, there is no significant difference (alpha 5 per cent) between the performances of the two model versions.

Cultivated lands were found to be on average five times more prone to erosion than bush-shrub lands. The predicted soil loss values in most parts of Gindae catchment are generally high as compared with the soil formation rates. This emphasises the importance of implementing appropriate soil and water conservation measures in critical sediment source areas prioritising the steepest part of the catchment (i.e. areas with slope $>50$ per cent).

The applicability of the WATEM/SEDEM model to environments where gully erosion is important requires the incorporation of permanent gully and bank gully erosion in the model structure. Copyright (C) 2011 John Wiley \& Sons, Ltd.
\end{abstract}

KEY WORDS: $\quad$ transport capacity; calibration; sediment yield; critical sediment-source areas; gully erosion; Ethiopia; soil erosion; sediment delivery model

\section{INTRODUCTION}

The risk of reservoir sedimentation in Tigray, northern Ethiopia, was poorly addressed in recent years during project planning because of a lack of sufficient environmental data, a lack of appropriate methodologies to predict sediment yield and the absence of catchment management strategies (Haregeweyn et al., 2006). This highlights the need for regional-scale sediment delivery models allowing delineation of critical sediment source areas that need to be prioritised for soil conservation. Critical sediment source areas or erosion hotspots are defined as parts

*Correspondence to: N. Haregeweyn, Department of Land Resources Management and Environmental Protection, Mekelle University, PO Box 231, Mekelle, Ethiopia.

E-mail: nigussie_haregeweyn@yahoo.com of the catchment with high erosion rates and high sediment transport capacities (e.g. McDowell and Srinivasan, 2009). The identification of such hotspots will help in applying a targeted response directing resources to areas of high risk rather than spreading them equally across the landscape (Boardman, 1995; Verstraeten et al., 2002; McDowell and Srinivasan, 2009).

This requires a basic understanding of the spatial patterns, rates and processes of soil erosion and sediment transport at the scale of a river catchment. However, in developing countries where spatial data is often scarce, possibilities to model spatial patterns of sediment delivery and to identify source areas of sediment are very limited.

Most regional-scale soil erosion models are lumped models based on empirical regression equations that predict sediment yield (e.g. Merritt et al., 2003; de Vente and Poesen, 2005; 
Haregeweyn, 2006). Inherent to this lumped approach is that it is not possible to take into account the spatial structure of land use and topography within the catchment. This limits their application to practical problems such as the evaluation of the impacts of different land management strategies on sediment delivery (Van Rompaey et al., 2001).

To overcome these problems, spatially distributed, processbased models can be used. Several attempts have been made to use such process-based models in Ethiopia such as the Water Erosion Prediction Project model (Gete, 1999), the Agricultural Non Point Source Pollution model (Haregeweyn and Yohannes, 2003; Hussen et al., 2004) or the Limburg Soil Erosion Model (Hengsdijk et al., 2005). However, such models require large amounts of input data whereas the return in increased accuracy of soil erosion prediction is limited (Jetten et al., 2003). If such models are applied in conditions where the necessary data are not available and/or a proper calibration cannot be performed, the results may become completely unreliable (Nyssen et al., 2006a).

Spatially distributed empirical or conceptual models may form an alternative to the complex physics-based spatially distributed models. The WATEM/SEDEM [WAter and Tillage Erosion Model/SEdiment DElivery Model (Van Oost et al., 2000; Van Rompaey et al., 2001)] was developed for prediction of sediment yield at the catchment scale with limited data requirements. This model predicts sediment yield at the catchment scale using a spatially explicit grid-cell based approach. It predicts long-term average annual soil loss and sediment delivery values and enables to explore the spatial patterns of soil erosion and sediment yield. Based on the spatial pattern of soil erosion and sediment yield, it is then possible to evaluate different scenarios for catchment management (Verstraeten et al., 2002), the impact of checkdams within the catchment and changing land uses (BoixFayos et al., 2008; Feng et al., 2010) and the identification of major sources and sinks of sediment (Alatorre et al., 2010) . Such a model therefore provides the information needed by planners and land managers without a heavy investment in data collection.

Currently, two versions of WATEM/SEDEM are in use. The difference between the two versions is in the transport capacity (TC) equation used. The first version, hereafter, called the 'original' was proposed by Van Rompaey et al. (2001) and was first calibrated on 20 catchments in the cultivated loess belt of central Belgium. This version of WATEM/ SEDEM has been applied in central Belgium (Van Oost et al., 2005; Verstraeten et al., 2002), hilly areas of the Czech Republic (Van Rompaey et al., 2003), Italian catchments located in various ecosystems (Van Rompaey et al., 2005) and in the Spanish Pyrenees (Alatorre et al., 2010). The second version of WATEM/SEDEM, hereafter called the 'modified' version was proposed and applied in southeast Australia by Verstraeten et al. (2007) and in Spain by de
Vente et al. (2008) and Boix-Fayos et al. (2008) to catchments where gullies are dominant. The TC-equation used in this modified version of WATEM/SEDEM considers sediment transport as a function of slope and upslope area and was expected to better reflect sediment transport because of concentrated overland flow in cases where the main valley bottoms of the catchment are subjected to gullying than the original TC-equation, which considers the transport capacity as a function of potential rill and interrill erosion (Van Rompaey et al. 2001). A detailed description of the two versions is given under the Description of the WATEM/ SEDEM model Section.

It is, however, not known to what extent WATEM/ SEDEM could be applied to the tropical highlands of Africa, which are characterised by steep topography, erosive rainfall, intensive land use and consequently high erosion and sedimentation rates. Such a simplified model can provide significant spatial information on erosion and sediment delivery at catchment scale, which is important for countries like Ethiopia, where there is a lack of spatial data. Furthermore, the relative performance of the two versions of WATEM/ SEDEM has never been assessed so far.

Therefore, the objectives of this study were as follows: (i) to calibrate and assess the performance of the spatially distributed WATEM/SEDEM model in predicting absolute sediment yield $(S Y)$ and specific sediment yield $(S S Y)$ by using two different sediment TC-equations (original and modified) and (ii) to assess the performance of the WATEM/SEDEM for identification of critical erosionsource areas for catchment management.

\section{MATERIALS AND METHODS}

\section{Study Area}

This study was carried out in 12 catchments in Tigray (northern Ethiopia) located in a radius of $120 \mathrm{~km}$ from Mekelle, Tigray's regional capital (Figure 1). The characteristics of the 12 catchments are given in Table I.

Tigray is one of the Ethiopian regional states located in the northern part of the country between $12^{\circ} 15^{\prime} \mathrm{N}$ and $14^{\circ} 50^{\prime} \mathrm{N}$ and $36^{\circ} 27^{\prime} \mathrm{E}$ and $39^{\circ} 59^{\prime} \mathrm{E}$. The region has a total area of $50078 \mathrm{~km}^{2}$ (of which 19 per cent is suitable for cultivation) and a population of more than 3.8 million (CSA, 2001). The climate is generally characterised as tropical semi-arid (Virgo and Munro, 1978) with an annual rainfall ranging from $450 \mathrm{~mm}$ in the north, east and central zones to $980 \mathrm{~mm}$ in the southern and western parts of the region. Most of the rainfall occurs in July, August and September (Haregeweyn, 2006). The topography of the region mainly consists of highland plateaus up to $3900 \mathrm{~m}$ a.s.l., which are dissected by gorges. The north-western part of the region is characterised by lowlands with elevations as low as $500 \mathrm{~m}$ a.s.l. The highlands support a high population 


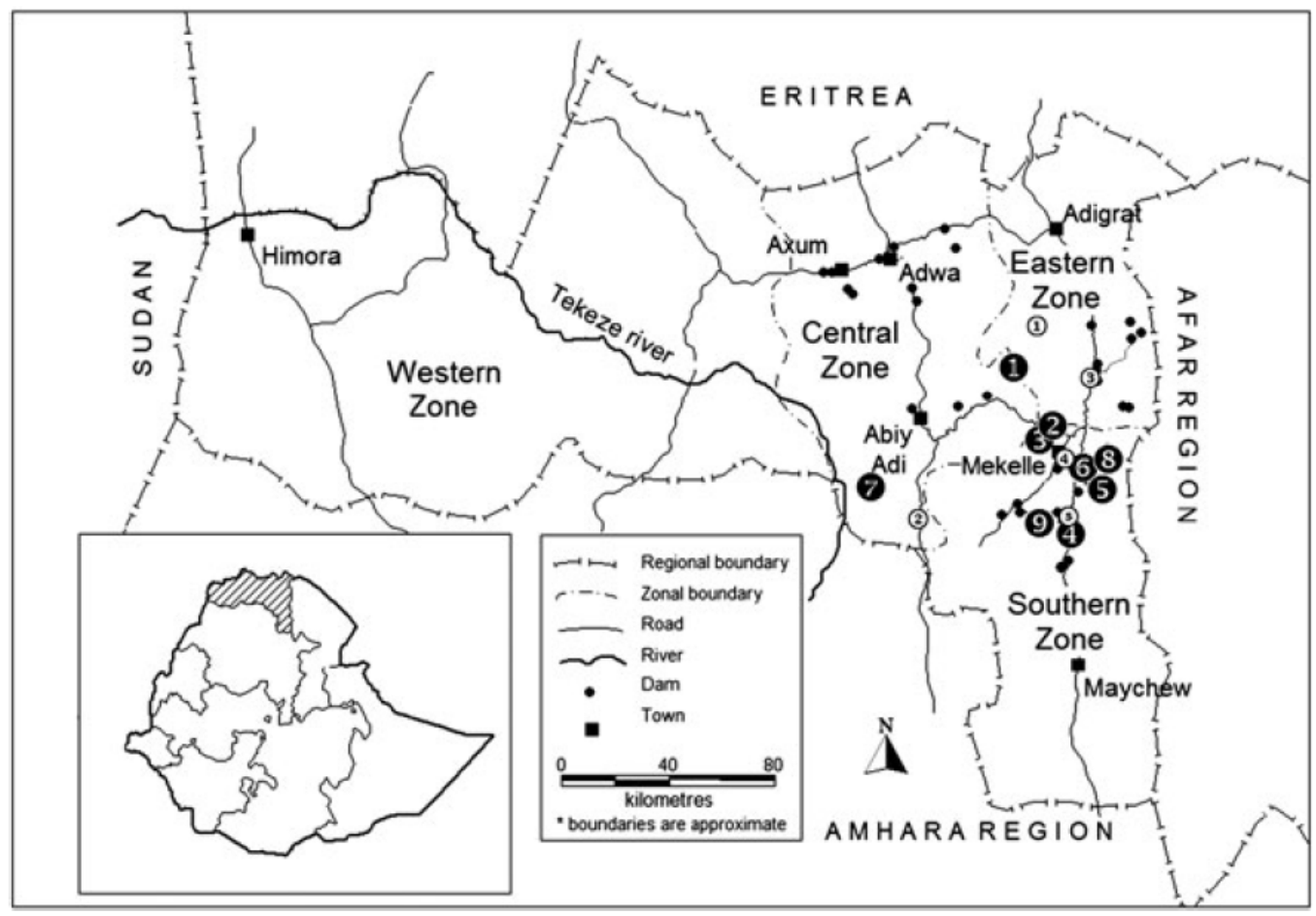

Figure 1. Location of the study area and the studied reservoirs. Dots represent reservoirs visited, numbers with black background fill represent reservoirs for which sediment yield was measured: 1 Gindae, 2 Gereb Shegel, 3 Sewhimeda, 4 (Gereb Segen, Grashitu, Mejae, Maideli, Gum Selassa), 5 Adiakor, 6 Adihilo, 7 Agushella, 8 Endazoey, 9 Adikenafiz. Numbers with white background fill represent rainfall stations: 1 Hawzen, 2 Yechila, 3 Wukro, 4 Mekelle airport, 5 Adigudom. The stations are owned and run by the National Meteorological Agency. Agushella catchment was not included in this study for lack of spatial data on catchment characteristics.

Table I. Characteristics of the 12 selected reservoirs and their corresponding catchments in northern Ethiopia

\begin{tabular}{|c|c|c|c|c|c|c|c|c|c|c|c|}
\hline \multirow{2}{*}{ Catchment } & \multirow{2}{*}{$\begin{array}{c}A \\
\left(\mathrm{~km}^{2}\right)\end{array}$} & \multirow{2}{*}{$\begin{array}{c}S G V \\
\left(\mathrm{~m}^{3} \mathrm{~km}^{-2}\right)\end{array}$} & \multirow{2}{*}{$\begin{array}{l}\text { Gully } \\
\text { erosion }\end{array}$} & \multirow{2}{*}{$\begin{array}{l}T D L \\
(\mathrm{~km})\end{array}$} & \multirow{2}{*}{$\begin{array}{l}S W C \\
(\%)\end{array}$} & \multicolumn{4}{|c|}{ Land use $(\%)$} & \multirow{2}{*}{$\begin{array}{l}\text { Average } \\
\text { slope }(\%)\end{array}$} & \multirow{2}{*}{$\begin{array}{l}\text { Soil } \\
\text { texture }\end{array}$} \\
\hline & & & & & & Cultivated & $\begin{array}{l}\text { Degraded } \\
\text { grazing }\end{array}$ & $\begin{array}{c}\text { Degraded } \\
\text { bush-shrub }\end{array}$ & Others & & \\
\hline Adiakor & $2 \cdot 92$ & 574 & Medium & $7 \cdot 228$ & 50 & 72 & 24 & 0 & 4 & $7 \cdot 12$ & Silt-loam \\
\hline Adihilo & 0.72 & 10010 & Low & $1 \cdot 160$ & 33 & 26 & 13 & 60 & 1 & $13 \cdot 36$ & Silt-clay \\
\hline Adikenafiz & $14 \cdot 30$ & 31764 & Medium & $34 \cdot 710$ & 41 & 65 & 9 & 24 & 9 & $15 \cdot 39$ & Sandy-loam \\
\hline Endazoey & 1.40 & 7512 & High & 5.980 & 50 & 45 & 20 & 31 & 4 & $11 \cdot 25$ & $\begin{array}{l}\text { Sandy-clay } \\
\text { loam }\end{array}$ \\
\hline $\begin{array}{l}\text { Gereb } \\
\text { Segen }\end{array}$ & $4 \cdot 35$ & 19380 & High & $9 \cdot 940$ & 8 & 86 & 5 & 8 & 1 & $3 \cdot 28$ & Clay \\
\hline $\begin{array}{l}\text { Gereb } \\
\text { Shegel }\end{array}$ & $8 \cdot 58$ & 17299 & Low & $13 \cdot 040$ & 86 & 19 & 34 & 42 & 4 & 19.36 & Loam \\
\hline Gindae & 11.87 & 19061 & Low & $22 \cdot 170$ & 40 & 25 & 32 & 37 & 6 & $14 \cdot 19$ & Clay-loam \\
\hline Grashitu & $5 \cdot 11$ & 11290 & High & 11.090 & 2 & 85 & 7 & 4 & 3 & $5 \cdot 36$ & Clay \\
\hline $\begin{array}{l}\text { Gum } \\
\text { Selassa }\end{array}$ & $24 \cdot 14$ & 6220 & Medium & $22 \cdot 480$ & 15 & 79 & 15 & 1 & 5 & $3 \cdot 38$ & Clay \\
\hline Maideli & $10 \cdot 05$ & 13390 & High & $15 \cdot 620$ & 10 & 56 & 6 & 32 & 6 & 8.00 & Clay \\
\hline Mejae & $2 \cdot 56$ & 2995 & Medium & $4 \cdot 190$ & 28 & 77 & 10 & 7 & 6 & $6 \cdot 70$ & Clay \\
\hline Sewhimeda & $5 \cdot 80$ & 418 & Low & $7 \cdot 228$ & 50 & 26 & 31 & 23 & 10 & $8 \cdot 45$ & Loam \\
\hline
\end{tabular}

$A$, catchment area; $S G V$, specific gully volume; $T D L$, total drainage length; $S W C$, fraction of catchment area where soil and water conservation measures are applied. Average slope is derived from digital elevation model.

Gully erosion: high, low or medium is based on field observations and ratings where high stands for dominance of gully headcut erosion, medium for mature gullies and low for old and/or stabilised gullies.

Soil texture is based on USDA Soil Textural Classification.

The grazing and bush-shrub lands are classified as 'degraded' because they did not meet the standard definition given for the corresponding land use type in FAO (2008). 
density (40-70 persons $\mathrm{km}^{-2}$; FAO, 2004) and are seriously affected by land degradation because of their long cultivation history (starting 3000 BC; Hurni, 1989; Bard et al., 2000), steep topography and erosive rains. In contrast, the lowlands are sparsely populated and have soils that are less eroded and degraded (TFAP, 1996).

\section{Assessment of Sediment Yield}

For all catchments, sediment yield data were derived from reservoir sedimentation surveys. Here, the term sediment yield refers to the total sediment outflow from a catchment measured at the point where the reservoirs are located for a specific period of time. It can be expressed in absolute terms as $S Y$ or in $S S Y$ as follows:

$$
\begin{gathered}
S Y=\frac{100 * S M}{S T E * Y} \\
S S Y=\frac{S Y}{A}
\end{gathered}
$$

Where: $S Y$ is the absolute sediment yield $\left(\mathrm{t}^{-1}\right), S M$ is the total sediment mass (t), STE is the sediment trap efficiency (per cent), $Y$ is the age of the reservoir (years), SSY is the specific sediment yield $\left(\mathrm{t} \mathrm{km}^{-2} \mathrm{y}^{-1}\right)$ and $A$ is the catchment area $\left(\mathrm{km}^{2}\right)$. With

$$
S M=S V^{*} d B D
$$

Where: $S V$ is the measured volumetric sediment input in the reservoir $\left(\mathrm{m}^{3}\right)$ and $d B D$ is the area-weighted average dry bulk density of the sediment $\left(\mathrm{t} \mathrm{m}^{-3}\right)$.

Sediment thickness was measured by observing sediment profiles (up to $4 \mathrm{~m}$ deep) in pits along transects with 15 to 39 pits per reservoir depending on the size and nature of the original bottom surface of the reservoir (see example in Figure 2). Sediment volume was computed by constructing a digital elevation model (DEM) with a resolution of $1 \mathrm{~m}$ using triangulated irregular network interpolation in IDRISI ${ }^{\circledR}$ (Clark Labs., Worcester, MA, USA) and taking sediment thickness as the $z$ value.

Sediment trap efficiency is the percentage of the total incoming sediment, which is retained in the reservoir. The STE was assessed based on one-season field monitoring in summer 2003 following the procedure that related sediment inflow to outflow as outlined in Verstraeten and Poesen 2000 as well as by interviewing the local farmers about the history of the reservoir on the frequency of overflow via the spillway. All reservoirs are less than 7 years old and spillage never occurred for eight of the reservoirs since their construction (Table II).

Sediment yield data are generally expressed in mass units $(\mathrm{t})$. Hence, the measured sediment volumes need to be converted to sediment masses using representative values of sediment bulk density. Dry bulk density was determined by gravimetric method. A total of 98 undisturbed representative sediment samples, which varied from 8 to 12 sampling sites per reservoir (near the dam axis, in the middle, at the side and inlet of the reservoir) and at a minimum of two different depths (top $0.30 \mathrm{~m}$ and bottom, which could go up to $4 \mathrm{~m}$ such as in Adikenafiz Reservoir) were taken using core rings (volume $=1 \times 10^{-4} \mathrm{~m}^{3}$ ). Sediment yield data for the 12 catchments are given in Table II, whereas details on reservoir sediment survey can be found in Haregeweyn et al. (2006).

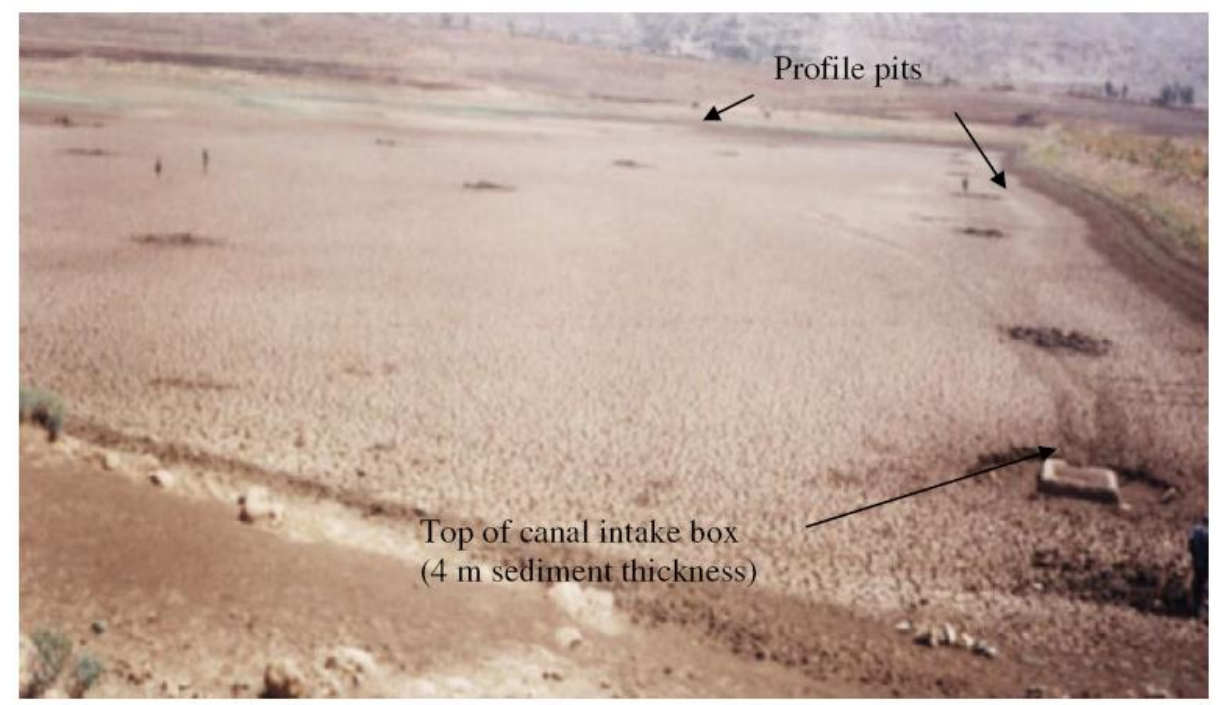

Figure 2. Layout of reservoir sediment profile pits in Adikenafiz reservoir. The top of inlet canal was clogged because of excessive sediment deposition and is shown cleared from sediment. This figure is available in colour online at wileyonlinelibrary.com/journal/ldr 
Table II. Sediment yield data for the 12 catchments in northern Ethiopia

\begin{tabular}{|c|c|c|c|c|c|c|c|}
\hline Reservoir & $S V\left(10^{3} \mathrm{~m}^{3}\right)$ & $S M\left(10^{3} \mathrm{t}\right)$ & $d B D\left(\mathrm{tm}^{-3}\right)$ & $Y$ (years) & STE $(\%)$ & $S Y\left(\mathrm{ty}^{-1}\right)$ & $S S Y\left(\mathrm{t} \mathrm{km}^{-2} \mathrm{y}^{-1}\right)$ \\
\hline Adihilo & 2 & 3 & $1 \cdot 38$ & 5 & 100 & 684 & 950 \\
\hline Endazoey & 4 & 5 & 1.07 & 5 & 100 & 973 & 695 \\
\hline Gereb Segen & 12 & 15 & $1 \cdot 23$ & 3 & 100 & 5140 & 1182 \\
\hline Gereb Shegel & 19 & 21 & $1 \cdot 11$ & 5 & 100 & 4180 & 487 \\
\hline Gum Selassa & 111 & 112 & 1.01 & 7 & 90 & 17767 & 736 \\
\hline Maideli & 67 & 70 & 1.08 & 5 & 98 & 14359 & 1429 \\
\hline Mejae & 6 & 8 & 1.42 & 5 & 100 & 1580 & 617 \\
\hline Sewhimeda & 4 & 6 & $1 \cdot 30$ & 5 & 100 & 1115 & 192 \\
\hline Average & 36 & 39 & $1 \cdot 20$ & 5 & 97 & 7499 & 922 \\
\hline$S D$ & 41 & 41 & $0 \cdot 13$ & 1 & 5 & 7165 & 484 \\
\hline
\end{tabular}

$S V$, total sediment volume; $S M$, total sediment mass; $d B D$, dry bulk density; $Y$, age of reservoir; $S T E$, sediment trap efficiency; $S Y$, absolute sediment yield; $S S Y$, specific sediment yield; $S D$, standard deviation.

\section{Description of the WATEM/SEDEM Model}

WATEM/SEDEM is a sediment delivery model that predicts how much sediment is transported to the river channel on an annual basis. It is a spatially distributed model, which means that the landscape is divided into small spatial units or grid cells. For an acceptable model performance, the size of the grid-cell should not exceed $100 \mathrm{~m} \times 100 \mathrm{~m}$ (Van Rompaey et al., 2001).

WATEM/SEDEM has the following three components: (i) soil loss assessment; (ii) sediment transport capacity assessment; and (iii) sediment routing, which are explained in more detail in the succeeding text. For each of the grid cell, mean annual soil erosion and mean annual transport capacity are calculated (Van Rompaey et al., 2001).

\section{Assessment of the mean annual soil erosion rate}

WATEM/SEDEM has the option to simulate both tillage and water erosion. In this study, however, the model was used to simulate the water erosion component only as it is by far the dominant erosion process in the study area (e.g. Nyssen et al., 2004). The water erosion component of WATEM/SEDEM uses an adapted version of the Revised Universal Soil Loss Equation (RUSLE; Renard et al., 1997):

$$
S L=R * K * L S_{2 \mathrm{D}} * C *(P)
$$

Where: $S L$ is the mean annual soil loss $\left(\mathrm{kg} \mathrm{m}^{-2} \mathrm{y}^{-1}\right), R$ is the rainfall erosivity factor $\left(\mathrm{MJ} \mathrm{mm} \mathrm{m}^{-2} \mathrm{~h}^{-1} \mathrm{y}^{-1}\right), K$ is the soil erodibility factor $\left(\mathrm{kg} \mathrm{h} \mathrm{MJ}^{-1} \mathrm{~mm}^{-1}\right), L S_{2 \mathrm{D}}$ is the two dimensional slope and slope-length factor, which was introduced by Desmet and Govers (1996a), $C$ is the crop management factor and $P$ is the erosion control practice factor. The latter was not taken into account in the original WATEM/SEDEM but has been added to the equation for the purpose of this study given the high density of soil and water conservation measures in the study area (Munro et al., 2008).

In order to adapt the RUSLE to a two-dimensional landscape, the upslope length was replaced by the unit contributing area, that is, the upslope drainage area per unit of contour length. The latter was calculated using the procedure proposed by Desmet and Govers (1996a).

\section{Assessment of the mean annual transport capacity}

The transport capacity is the maximum mass of the soil that can exit a grid-cell per unit length of the down slope face of the square. For each grid-cell, a mean annual TC $\left(\mathrm{kg} \mathrm{m}^{-1}\right)$ was assessed. For each land use type, transport capacity can be different. For central Belgium, WATEM/SEDEM was calibrated for arable land with high transport capacity (KTC_arable $)$ and non-arable land with a relatively low transport capacity.

The original TC version (Van Rompaey et al., 2001) assumes that sediment transport capacity is proportional to the potential rill and inter-rill erosion by calculating $\mathrm{TC}$ as follows:

$$
T C=K T C * R * K *\left(L S_{2 \mathrm{D}}-4.1 S_{\mathrm{IR}}\right)
$$

Where: $T C$ is the transport capacity $\left(\mathrm{kg} \mathrm{m}^{-1} \mathrm{y}^{-1}\right), K T C$ is the transport capacity coefficient $(\mathrm{m})$ and $S_{\mathrm{IR}}$ is the interrill slope gradient $\left(\mathrm{m} \mathrm{m}^{-1}\right)$. The transport capacity coefficient $K T C(\mathrm{~m})$ describes the proportionality between the potential for rill erosion and the transport capacity. It can be interpreted as the theoretical upslope distance that is needed to produce enough sediment to reach the transport capacity at the grid cell, assuming a uniform slope and runoff discharge. 
The inter-rill slope gradient is calculated based on the equation proposed by Govers and Poesen (1988) as follows:

$$
S_{\mathrm{IR}}=6.86 S_{\mathrm{g}}^{0.8}
$$

Where: $S_{\mathrm{g}}$ is the slope gradient $\left(\mathrm{mm}^{-1}\right)$.

The second (modified) version of TC was presented by Verstraeten et al. (2007) as follows:

$$
T C=K T C * R * K^{*} A^{1.4} * S^{1.4}
$$

Where: $K T C$ reflects the land use component, $A$ stands for contributing upslope area per unit of contour length $\left(\mathrm{m}^{2} \mathrm{~m}^{-1}\right)$ and $S$ for local slope gradient $\left(\mathrm{m} \mathrm{m}^{-1}\right)$. This equation is based on the widely used equation predicting sediment transport as a function of runoff discharge and slope gradient (e.g. Beasly et al., 1980; Prosser and Rustomji, 2000). Runoff discharge in this equation is replaced by upslope contributing area. The exponents reflect landscape characteristics that influence sediment transport such as rainfall intensity, soil erodibility and vegetation and landscape characteristics that influence runoff generation. Based on a review made by Prosser and Rustomji (2000), values of 1.4 were selected as these were the mean values derived from a large number of studies. Van Rompaey et al. (2001) found that it was useful to make a distinction between the transporting capacity on arable land and on non-arable land by using two different $K T C$ values. We used the same approach in this study.

\section{Sediment routing}

WATEM/SEDEM employs a routing algorithm to transfer the eroded sediment from the source to the river network. By means of a multiple flow routing algorithm (Desmet and Govers 1995, 1996b), each grid-cell starting from the highest grid cells in the landscape is connected with the river via a unique flow path. The construction of flow paths starts by determining the outflow cell for the grid cell in the upper left corner of the DEM using the steepest descent criterion. This means that the lowest of the eight neighbouring cells is selected as an outflow cell. Next, the outflow cell of the former outflow cell is determined. This procedure is repeated until a river channel, the border of the DEM or an existing flow path is reached. Following the flow path, the sediment is transferred further downslope if the local transport capacity exceeds the incoming sediment volume. If the local transport capacity is lower than the incoming sediment, deposition occurs. Moreover, at catchment scale, the spatial pattern and type of land use are relevant to water erosion because changes in land use can alter the hydrological structure and thus the erosion system within a catchment (Van Oost et al., 2000). For instance, field boundaries, roads and other landscape structures affect the sediment and/or runoff transfer between different land units. This effect is well accounted in WATEM/SEDEM by incorporating a parcel map. Sediment that reaches the river channel is considered to leave the catchment. Neither channel erosion nor deposition is predicted by the model.

\section{WATEM/SEDEM Input Data}

\section{RUSLE data layers}

Geographic information system data layers were prepared representing the different RUSLE factors of Equation (4) at a spatial resolution of $20 \mathrm{~m}$. As the erosion component of the WATEM/SEDEM was based on RUSLE (Renard, et al., 1997), calibrated values for some of the Universal Soil Loss Equation (USLE) parameters for Ethiopia (Hurni, 1985) were used as input to the erosion component (Table III). For instance, the rainfall erosivity value $(R)$ was derived from the relationship between annual rainfall and annual erosivity expressed in $\mathrm{J} \mathrm{cm} \mathrm{m}^{-2} \mathrm{~h}^{-1} \mathrm{y}^{-1}$. Rainfall records for the period 1998-2005 in four meteorological stations representing the study catchments (Figure 1) showed an overall mean annual average rainfall ranging between 560 and $600 \mathrm{~mm}$, which correspond to an average $R$ value of $0.30 \mathrm{MJ}$ $\mathrm{mm} \mathrm{m}^{-2} \mathrm{~h}^{-1} \mathrm{y}^{-1}$. Because of the lack of continuous rainfall records in the study sites, it was not possible to apply the more detailed equations for $R$ estimation proposed by Krauer (1988) and Nyssen et al. (2005).

The $K$-factor was determined using Eq. 8 as proposed by Declercq and Poesen (1991) as follows:

$$
K=3.5+38.8 \mathrm{e}-0.5\left(\frac{\log D g+1.519}{0.7584}\right)^{2}
$$

Where: $K$ is the soil erodibility factor $\left(\mathrm{kg} \mathrm{h} \mathrm{MJ}^{-1} \mathrm{~mm}^{-1}\right)$ and $D g$ is the geometric mean particle diameter $(\mathrm{mm})$. Soil texture information was obtained from the soil texture map (scale 1:50 000), which was produced based on a field-based soil mapping campaign. Representative samples from the top $10 \mathrm{~cm}$ from each soil unit were taken and analysed for soil texture by using hydrometer analysis following the procedures proposed by Gee and Bauder (1982). In catchments where there was significant stone cover (i.e. above 10 per cent), the effect of rock fragment cover was taken into account by applying the following equation proposed by Poesen et al. (1994):

$$
I R R=e^{-0.04(R c-10)}
$$

Where: IRR is the mean relative inter-rill and rill sediment yield, $R c$ is the rock fragment cover (per cent) with 10 per cent $<R e<100$ per cent and 0.04 is the mean rate of decay of IRR with increasing $R c$.

Nyssen et al. (2004) indicated that the slope gradient factor 'S' from the USLE (Wischmeier and Smith, 1978) is for slope 
Table III. The Universal Soil Loss Equation adapted to Ethiopian conditions (after Hurni, 1985)

\begin{tabular}{|c|c|c|c|c|c|c|c|c|}
\hline \multicolumn{9}{|l|}{ 1. $R$ : Rainfall erosivity } \\
\hline Annual rainfall (mm) & 100 & 200 & 400 & 800 & 1200 & 1600 & 2000 & 2400 \\
\hline Annual factor $R$ & 48 & 104 & 217 & 441 & 666 & 890 & 1115 & 1340 \\
\hline \multicolumn{9}{|l|}{ 2. $K$ : Soil erodibility } \\
\hline Soil colour & Black & & Brown & & Red & & Yellow & \\
\hline Factor $K$ & $0 \cdot 15$ & & $0 \cdot 20$ & & $0 \cdot 25$ & & $0 \cdot 30$ & \\
\hline \multicolumn{9}{|l|}{ 3. $L$ : Slope length } \\
\hline Length (m) & 5 & 10 & 20 & 40 & 80 & 160 & 240 & 320 \\
\hline Factor $L$ & $0 \cdot 5$ & 0.7 & $1 \cdot 0$ & $1 \cdot 4$ & 1.9 & $2 \cdot 7$ & $3 \cdot 2$ & $3 \cdot 8$ \\
\hline \multicolumn{9}{|l|}{ 4. $S$ : Slope gradient } \\
\hline Slope $(\%)$ & 5 & 10 & 15 & 20 & 30 & 40 & 50 & 60 \\
\hline Factor $S$ & $0 \cdot 4$ & $1 \cdot 0$ & 1.6 & $2 \cdot 2$ & $3 \cdot 0$ & $3 \cdot 8$ & $4 \cdot 3$ & $4 \cdot 8$ \\
\hline \multicolumn{9}{|l|}{ 5. $C$ : Land cover } \\
\hline Dense forest & & & $0 \cdot 001$ & & Dense grass & & & $0 \cdot 01$ \\
\hline Other forest & & & See grass & & Degraded grass & & & 0.05 \\
\hline Badlands hard & & & 0.05 & & Fallow hard & & & 0.05 \\
\hline Badlands soft & & & $0 \cdot 40$ & & Fallow ploughed & & & $0 \cdot 60$ \\
\hline Sorghum, maize & & & $0 \cdot 10$ & & Ethiopian tef & & & $0 \cdot 25$ \\
\hline Cereals, pulses & & & $0 \cdot 15$ & & Continuous tef & & & $1 \cdot 00$ \\
\hline \multicolumn{9}{|l|}{ 6. $P$ : Management factor } \\
\hline Ploughing up and down & & & $1 \cdot 00$ & & Ploughing on contour & & & $0 \cdot 90$ \\
\hline Strip cropping & & & $0 \cdot 80$ & & Intercropping & & & $0 \cdot 80$ \\
\hline Applying mulch & & & $0 \cdot 60$ & & Dense intercropping & & & $0 \cdot 70$ \\
\hline Stone cover $80 \%$ & & & $0 \cdot 50$ & & & & & \\
\hline Stone cover $40 \%$ & & & $0 \cdot 80$ & & & & & \\
\hline
\end{tabular}

$R$ in $\mathrm{Jcm} \mathrm{m}^{-2} \mathrm{~h}^{-1} \mathrm{y}^{-1}$ and $K$ also in SI units following Wischmeier and Smith's (1978) conversion coefficient.

gradients up to $0.22 \mathrm{~m} \mathrm{~m}^{-1}$ and is not valid for steeper slopes. Data collected in Simen (Hurni, 1979) showed that this equation cannot be extrapolated and that the curve expressing the relation between soil loss and slope gradient is flattening, an observation also made by Nearing (1997) in China. The slope function proposed by McCool et al. (1989) predicts a much slower increase of erosion with slope gradient than the original slope function of Wischmeier and Smith and has been commonly used in previous studies like Van Oost et al. (2000) and Van Rompaey et al. (2001) and is therefore also used in this study.

The $C$-factor was derived from the land use map by assigning $C$-factor values to each land use. An adapted $C$ factor was used for arable land with cereals and legumes, badlands and for forest (Table III). For other land uses like settlement areas and areas with rock mining activities, an appropriate $C$-factor value was chosen based on a combination of field-based expertise and also consulting related literature (Table IV). These types of land use only represented a minor part of the total surface area in the study catchments (Table I).

Soil and water conservation $(S W C)$ activities are of high importance for minimising erosion rates (Gebremichael et al., 2005) and off-site impacts of soil erosion such as reservoir sedimentation (Haregeweyn et al., 2005). Stone bunds are the most important implemented physical structures in the study area. A more comprehensive analysis on the type and effectiveness of $S W C$ practices implemented in Tigray can be found in Nyssen et al. (2010). The $P$-factor values for stone bunds were determined by Gebremichael et al. (2005). Their study concluded that stone bunds in this study reduced erosion rates by 68 per cent on average corresponding to a $P$-factor of $0 \cdot 32$. For traditional contouring without any other $S W C$ measures a $P$-factor of 0.8 was assumed. In the field, areas with different $S W C$ structures were mapped and given a score based on the structure quality (mainly spacing, continuity and height). P-values were then determined for each area with $S W C$ structures by interpolating a value between 0.8 and 0.32 based on the $S W C$ score (Table V).

\section{Digital elevation model}

The overall quality of the 3 arc-second SRTM DEM (http:// seamless.usgs.gov/) in terms of positional accuracy and

Table IV. $C$-factor values used in this study for different land use types (after Van de Sype, 2005)

\begin{tabular}{lc}
\hline Land use type & $C$-factor \\
\hline Settlements & $0 \cdot 01$ \\
Bush-shrub-grassland: degraded & $0 \cdot 05$ \\
Bush-shrub-grassland: exclosures & 0.03 \\
Rock mining & $0 \cdot 15$ \\
\hline
\end{tabular}

The values were determined based on Table III and also on field-based expertise discussion. Exclosures are defined as areas of natural vegetation protected from major degradation agents, such as humans and livestock. 
Table V. P-factor values corresponding to the various conditions of stone bund soil conservation practices (modified after Van de Sype, 2005)

\begin{tabular}{|c|c|c|}
\hline Conservation practices rating & Description & $P$-factor value \\
\hline 1 & Remains sporadic & $0 \cdot 70$ \\
\hline 3 & Moderate quality, moderate spacing $(>15 \mathrm{~m})$ and moderate dimensions $(<50 \mathrm{~cm}$ high $)$ & $0 \cdot 50$ \\
\hline 4 & Good quality, close spacing $(<10 \mathrm{~m})$, large dimensions $(>50 \mathrm{~cm}$ high) and backfill & $0 \cdot 32$ \\
\hline 5 & Impoundments like mining sites and trenches with negligible runoff and sediment yield & $0 \cdot 00$ \\
\hline
\end{tabular}

terrain representation was better than the DEM that could be derived from available contour maps (Haregeweyn, 2006). Hence, the SRTM DEM was used in this study.

\section{Parcel map}

It is well known that landscape structure can strongly affect soil erosion patterns and rates. Therefore, WATEM/SEDEM uses a parcel map so that effects of parcel boundaries and other landscape structures such as roads can be accounted for (Van Oost et al., 2000). However, it was practically impossible to map every parcel separately in the field. Alternatively, the parcel map was created by using the Thiessen interpolation analysis tool employing a randomly selected vector-file points generated from the catchment DEM using a 'spatial sampling' analysis tool in IDRISI ${ }^{\circledR}$. Two different parcel sizes of 0.25 ha and 0.50 ha were used depending on the size of the average parcels in the respective catchments. After polygon generation, the river and road layers were added to the parcel map using an overlay procedure.

\section{Contribution of Gully Erosion}

Both versions of the WATEM/SEDEM model are RUSLEbased (Renard et al., 1997) but adapted to a twodimensional landscape, that is, upslope length was replaced by the unit contributing area as proposed by Desmet and Govers (1996a). As verified by field observation in the Belgian loess belt, the adaptation enabled the model to account for not only inter-rill and rill erosion but also to some extent for ephemeral gully erosion as effects of flow convergence are explicitly accounted for (Desmet and Govers, 1997).

Field observations in the study area indicate that permanent valley-bottom gully erosion and in particular gully bank and headcut erosion are important erosion processes in the study area, although measured erosion rates and data on their relative contribution to sediment delivery into the reservoirs are not available. Nyssen et al. (2006b) estimated the short-term and long-term ( $>50$ years) specific gully erosion rates in Tigray at $1 \cdot 1$ and $6 \cdot 2 \mathrm{tha}^{-1} \mathrm{y}^{-1}$, respectively, though there are uncertainties in assessing the age of gullies especially for gullies older than 50 years. In this study, the significance of gully erosion was evaluated based on both (i) the magnitude of the specific gully incision volume (SGV) and (ii) the signs of active gully erosion observed in the field. Gullies were mapped and their dimensions (length, width, depth) were measured in the field by using global positioning system and a tape measure. The SGV was calculated by dividing the total gully volume by the corresponding catchment area (A). However, a high SGV does not necessarily indicate a high gully erosion rate at the present moment (Haregeweyn, 2006). Therefore, the SGV value was combined with signs of active gully erosion observed in the field to assess the performance of WATEM/ SEDEM in catchments undergoing different rates of gully erosion (Table I).

\section{Model Calibration and Evaluation}

WATEM/SEDEM was calibrated by changing the KTC values for different land use types. For all grid-cells with arable land, a $K T C$ threshold value of 0.01 was applied. For non-arable areas, a $K T C$ threshold value of 0.001 was used. However, it was found that the model result was insensitive to changes in the $K T C$ values of non- arable areas with low $C$-factors as there are only very few areas with a low $C$-factor. Nearly all catchments are dominantly characterised by cultivated and degraded grazing/bush land (Table I) where the latter is characterised by a higher $C$-factor $(>0 \cdot 01$, Table III) like that of arable land.

Therefore WATEM/SEDEM was first run for each individual catchment, for each model version (Eqs. 5 and 7) and for a wide range of KTC values for all the 12 catchments for which reservoir sedimentation data are available. Through this, the range of $K T C$ values to be used for more detailed calibration was defined. Then, within that range for each catchment, WATEM/SEDEM was run between 625 - and 1000 -times by increasing $K T C$ values by 10 and 2 each time for the original and modified model versions, respectively. Following this, an additional calibration was carried out using the data of only nine catchments, excluding Gereb Segen, Grashitu and Maideli catchments as sediment yield was found to be strongly underpredicted for the three catchments after calibration for 12 catchments. 
In all cases, default parcel connectivity values of 10 per cent and 75 per cent were adopted for cropland and grazingland/shrubland, respectively. Model runs for a range of parcel connectivity values for the two land use types showed that the model is not sensitive to changes of connectivity values.

Optimum KTC value was evaluated by comparing the deviation between the predicted sediment yields with the measured sediment yield. Optimum KTC value was evaluated by comparing the deviation between predicted and observed sediment yield and calculation of Nash and Sutcliffe (1970) model efficiency $(M E)$ as follows:

$$
M E=1-\frac{\sum_{i=1}^{n}(\mathrm{O} i-\mathrm{Pi})^{2}}{\sum_{i=1}^{n}\left(O i-O_{\text {mean }}\right)^{2}}
$$

Where: $M E$ is the model efficiency, $n$ is the number of observations, $O_{\text {mean }}$ is the mean observed value, $O_{i}$ is the observed value and $P_{i}$ is the predicted value. The value of $M E$ can range from $-\forall$ to 1 and represents the proportion of the initial variance accounted for by the model. The closer the value of $M E$ approaches 1, the more efficient is the model. Negative values of $M E$ indicate that the model produces more variation than was observed, that is, the model is inefficient.

The accuracy of model prediction for absolute $S Y$ and $S S Y$ was evaluated using the coefficient of determination $\left(r^{2}\right), M E$ and the relative root mean square error (RRMSE; Van Rompaey et al., 2001):

$$
\text { RRMSE }=\frac{\sqrt{\frac{1}{n} \sum_{i=1}^{n}(\mathrm{O} i-\mathrm{Pi})^{2}}}{\frac{1}{n} \sum_{i=1}^{n} \mathrm{Oi}}
$$

Where: RRMSE is the relative root mean square error, $O i$ is the observed value, $P i$ is the predicted value and $n$ is the number of observations. Values for RRMSE range from 0 to $\forall$. The closer the RRMSE approximates zero (=the perfect model), the better the model performance.

The predictive accuracy of the spatial distribution of erosion rates was assessed by relating the net erosion rate map predicted by the model with available literature on soil erosion rates for various land uses.

\section{RESULTS AND DISCUSSION}

\section{The Original WATEM/SEDEM Version}

Calibration of the original WATEM/SEDEM version for the whole dataset $(n=12)$ resulted in an optimal value for KTC_arable of $110 \mathrm{~m}$ with $M E=0.64$ (Figure 3; Table VI). There is quite a good correspondence between the observed and predicted mean annual $S Y$ (i.e. $r^{2}=0 \cdot 69, M E=0 \cdot 65$ and $R R M S E=54$ per cent; Table VI and Figure 4). On the other hand, $S S Y$ was poorly predicted (i.e. $r^{2}=0 \cdot 11, M E=-1 \cdot 15$ and $R R M S E=54$ per cent).

The overall performance was influenced by extreme overprediction of $S Y$, that is, 229 per cent for Sewhimeda catchment and underprediction for Gereb Segen, Madeli. Gum Selassa Grashitu catchments ranging between 43 and 63 per cent (Figure 5).

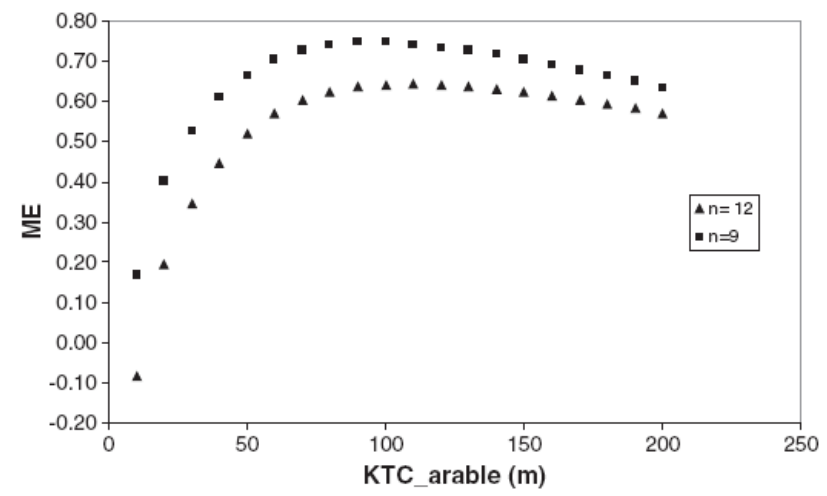

Figure 3. The original WATEM/SEDEM model KTC_arable calibration curve for northern Ethiopian catchments. The optimum KTC_arable values are $110 \mathrm{~m}$ and $90 \mathrm{~m}$ for the 12 and 9 catchments, respectively.

Table VI. Model performance indicators derived from calibration of the two WATEM/SEDEM versions and two regression models

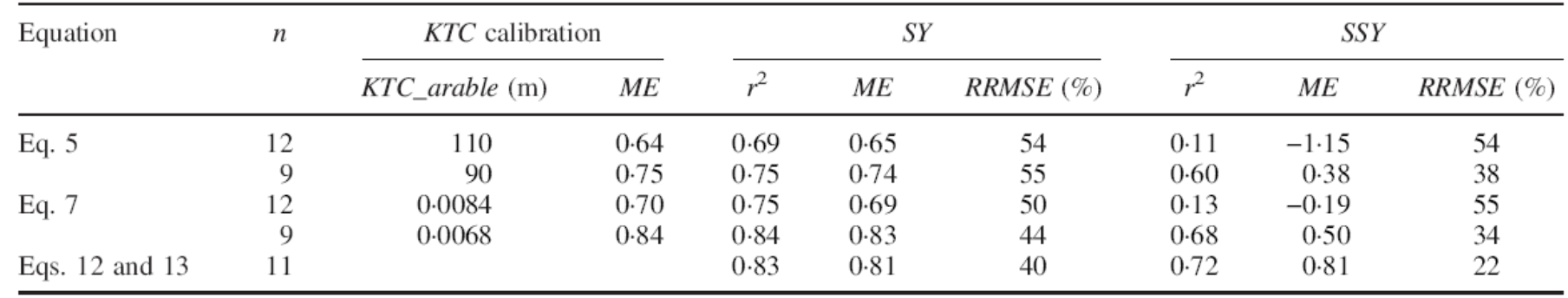

$n$, number of catchments considered; $K T C$, transport capacity coefficient; $M E$, model efficiency; $S Y$, absolute sediment yield; SSY, specific sediment yield; $r^{2}$, coefficient of determination; RRMSE, relative root mean square error. 


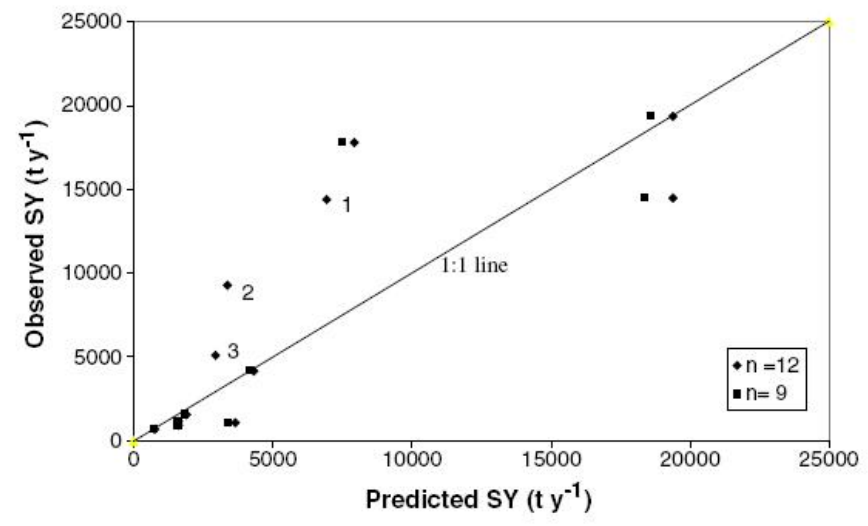

Figure 4. Performance of the original WATEM/SEDEM model in predicting sediment yield $(S Y)$ for northern Ethiopian catchments $(M E=$ $0.65, n=12 ; M E=0.74, n=9)$. The numbers 1,2 and 3 represent catchments with significant gully erosion: 1 Maideli, 2 Grashitu and 3 Gereb Segen.

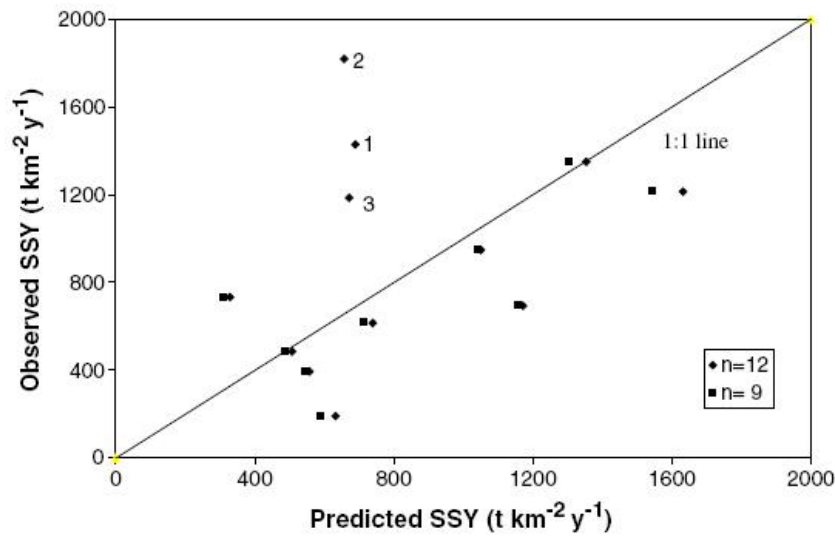

Figure 5. Performance of the original WATEM/SEDEM model in predicting specific sediment yield (SSY) for northern Ethiopian catchments $(M E=-1 \cdot 18, n=12 ; M E=0 \cdot 38, n=9)$. The numbers 1,2 and 3 represent catchments with significant gully erosion: 1 Maideli, 2 Grashitu and 3 Gereb Segen.

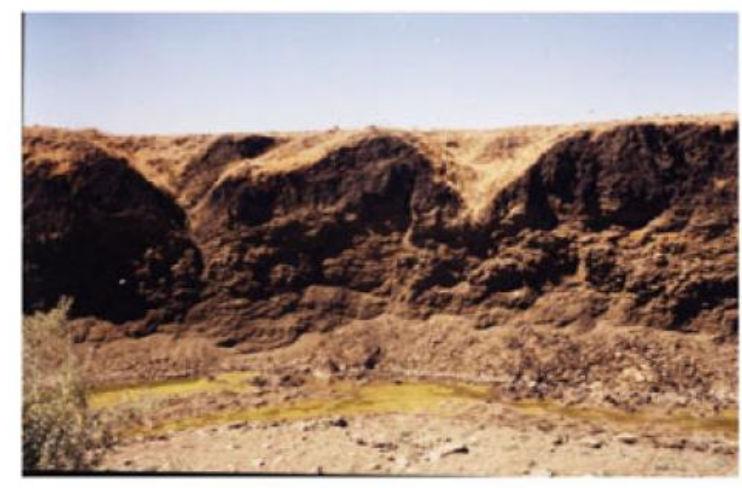

(a)

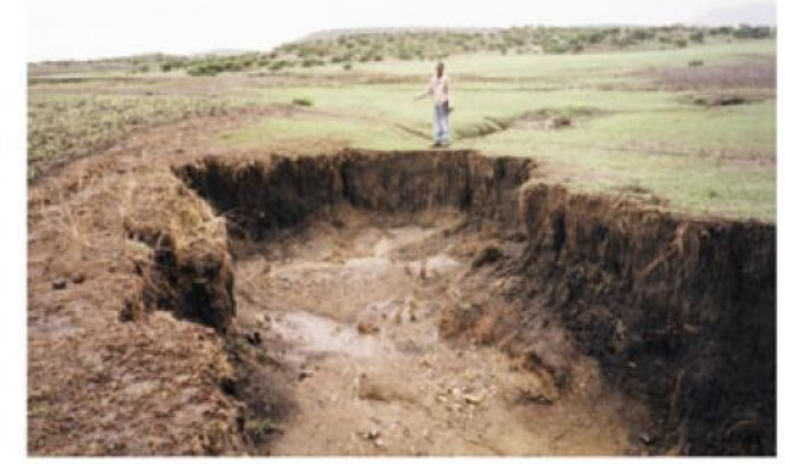

(b)

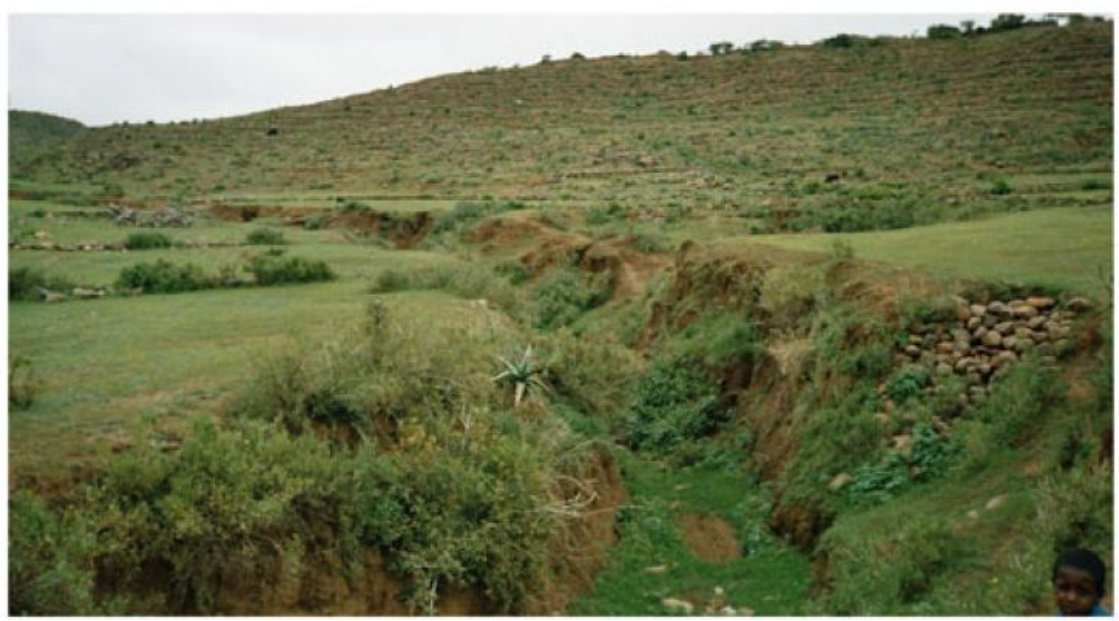

(c)

Figure 6. Illustration of gully erosion in the studied catchments, which is not accounted for by WATEM/SEDEM model. Gully-bank erosion in Grashitu (a) gullyhead retreat in Maideli (b) and a relatively stabilised gully in Sewhimeda (c). This figure is available in colour online at wileyonlinelibrary.com/journal/ldr 
The overprediction in Sewhimeda catchment is attributed to the presence of trenches resulting from rock mining activities covering 10 per cent of the total catchment area (Van de Sype, 2005). These trenches act as sediment and runoff impoundments, which consequently result in low $K T C$ and low sediment delivery ratio values. The sediment delivery ratio is defined as the ratio between sediment yield from the catchment and gross erosion as predicted by the WATEM/SEDEM.

The underprediction of $S Y$ in Greb Segen, Madeli and Grashitu cathments is partly attributed to the significant contribution of gully erosion. This model version has not taken into account the river component, that is, the contribution of river channel processes is assumed to be zero (Van Rompaey et al., 2005). The three catchments are characterised by high SGV (Table I) and by the presence of active gully erosion features (Figure 6). The high and active gully incision in those catchments can be due to the areawide presence of deep clay colluvial-alluvial deposits along the drainage lines [Figure 6(a) and (b)]. These deposits are characterised by a high desiccation cracks density during the long-dry season (8 months). As a result, pipes are initiated that facilitate mass slumping when saturated during the rainy season (Nyssen et al., 2004). On-the-other-hand, it seems unlikely that gullies fully account for the discrepancy between the predicted and the observed sediment yield for the three catchments. Although information on measured gully erosion rates and their contribution on the sediment delivery are not available at the scale of this study, comparison was however made with the work of Nyssen et al. (2006b) who estimated the short-term and long-term specific gully erosion rates in a range of smaller catchments at 111 and $622 \mathrm{t} \mathrm{km}^{-2} \mathrm{y}^{-1}$, respectively. The magnitude of the discrepancy between observed and predicted $S S Y$ was found to be higher than even the short-term sediment yield rates from gullies.

Consequently, the 12 catchments were divided into two datasets: one with the nine catchments where gully erosion activity is low to medium and the other with the three catchments with relatively high gully erosion. As a result, another optimal KTC_arable $(90 \mathrm{~m})$ with $M E=0.75$ was obtained for the nine catchments (Figure 3 and Table VI) and the correspondence between the observed and predicted sediment yield have improved; $r^{2}$ of 0.75 and $0.60, M E$ of 0.74 and 0.38 and RRMSE of 55 per cent and 38 per cent for $S Y$ and SSY, respectively (Table VI and Figures 4 and 5). Although the improvement in prediction of the $S Y$ was only slight, the performance in the prediction of $S S Y$ is clearly much better.

For these three gullied catchments, the model underestimated $S Y$ and $S S Y$. Even when very high $K T C$ values were used, the predicted total erosion is in the same order of magnitude as the measured sediment yield.

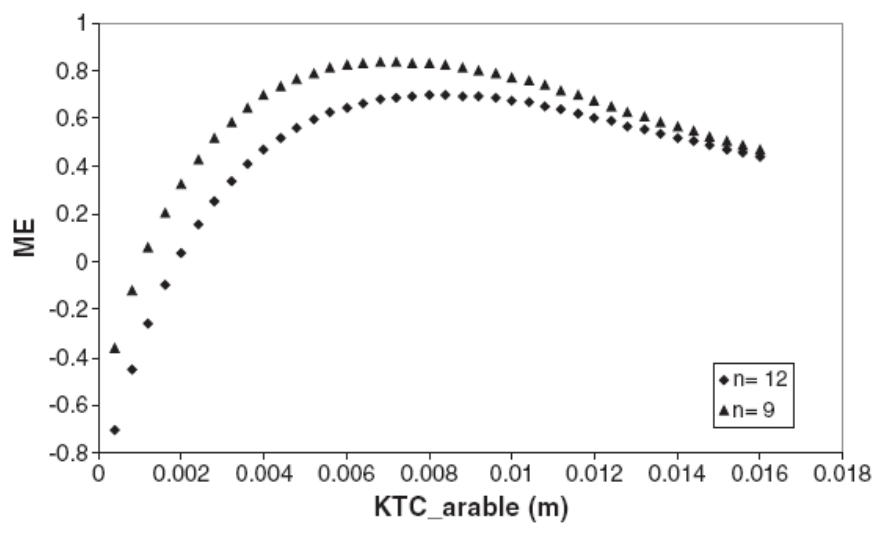

Figure 7. The modified WATEM/SEDEM KTC_arable calibration curve for northern Ethiopian catchments. The optimum KTC_arable values are 0.0084 and $0.0068 \mathrm{~m}$ for the 12 and 9 catchments, respectively.

\section{The Modified WATEM/SEDEM Version}

In the case of the modified model version, the optimal KTC_arable is $0.0084 \mathrm{~m}$ with $M E$ of 0.70 for the 12 catchments (Table VI and Figure 7). There is a good correspondence between the observed and the predicted $S Y$ with $r^{2}, M E$ and RRMSE of 0.75, 0.69 and 50 per cent, respectively (Table VI and Figure 8). This model version performed better in predicting both $S Y$ and $S S Y$ as compared with the original version of WATEM/SEDEM (Table VI) though the difference is minimal. Yet, like the original model version, the overall performance was influenced by a significant overprediction of sediment yield for Sewhimeda and Mejae catchments, that is, 142 per cent and 82 per cent, respectively, as well as by an underprediction for Gereb Segen, Madeli and Grashitu catchments, ranging between 53 per cent and 63 per cent (Figure 8). Similar reasons, for over and underprediction given for the original version apply to this modified model version too.

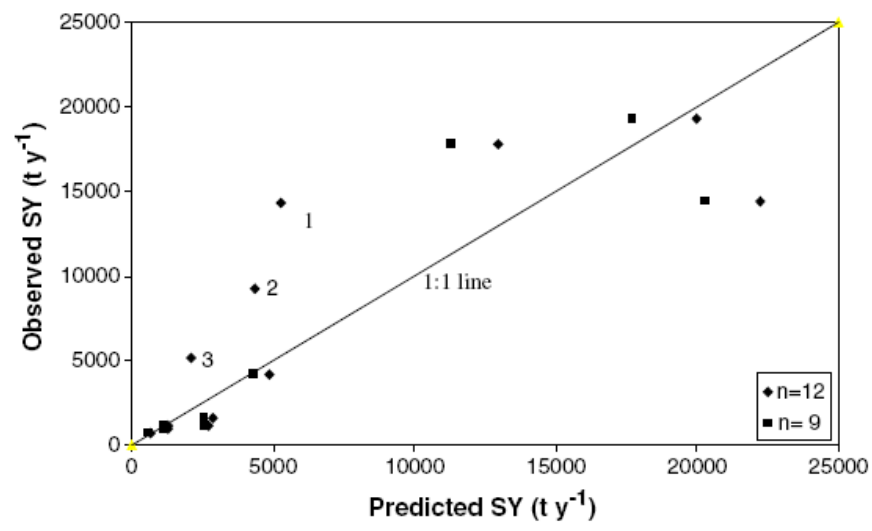

Figure 8. Performance of the modified WATEM/SEDEM model in predicting sediment yield $(S Y)$ for northern Ethiopian catchments $(M E=$ $0.69, n=12 ; M E=0.83, n=9)$. The numbers 1,2 and 3 represent catchments with significant gully erosion: 1 Maideli, 2 Grashitu and 3 Gereb Segen. 


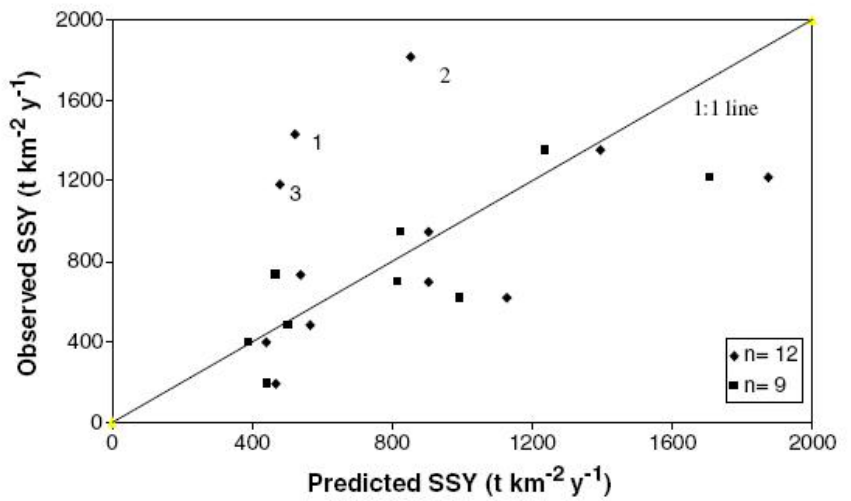

Figure 9. Performance of the modified WATEM/SEDEM in predicting specific sediment yield $(S S Y)$ for northern Ethiopian catchments $(M E=$ $-0 \cdot 19, n=12 ; M E=0 \cdot 50, n=9)$. The numbers 1,2 and 3 represent catchments with significant gully erosion: 1 Maideli, 2 Grashitu and 3 Gereb Segen.

Therefore, this model version was also calibrated for the nine catchments with low to medium observed gully erosion only. This resulted in an optimal KTC_arable of $0.0068 \mathrm{~m}$ with $M E$ of 0.84 (Table VI and Figure 7) and significantly improved predictions for $S Y$ and $S S Y$. The $r^{2}, M E$ and RRMSE for $S Y$ were $0.84,0.83$ and 44 per cent, respectively, whereas for $S S Y$, these statistical parameters equalled $0.68,0.50$ and 34 per cent, respectively (Table VI and Figures 8 and 9).

\section{The Performance of the two WATEM/SEDEM Model \\ Versions in Predicting Erosion and Sediment Yield}

Illustrations of the predicted pattern and rates of erosion and deposition within the catchment for the two versions of WATEM/SEDEM and their differences are given in Figure 10. The patterns of net erosion predicted by the modified and original version of WATEM/SEDEM look quite similar with a relatively small deposition rate observed in the modified version. A paired mean $t$-test however showed a non-significant difference (alpha 5 per cent) and a strong correlation between $S Y$ and $S S Y$ predictions with the two versions (Table VII). Therefore, it can be concluded that there is no clear difference in performance both in terms of pattern and rates of erosion between the two models. Moreover, both did not address fully the contribution of gully erosion.

The two WATEM/SEDEM model versions simulated $S Y$ with a reasonable accuracy, which is in line with similar studies reported for the loess belt of central Belgium

Figure 10. Gindae catchment. Spatial pattern of soil erosion and sediment deposition $\left(\mathrm{tha}^{-1} \mathrm{y}^{-1}\right)$ predicted by the two versions of WATEM/SEDEM model: the original (a), the modified (b) and the overlay (c) [subtraction of (b) from (a)]. Negative values represent net erosion, whereas positive values present net deposition. This figure is available in colour online at wileyonlinelibrary.com/journal/ldr

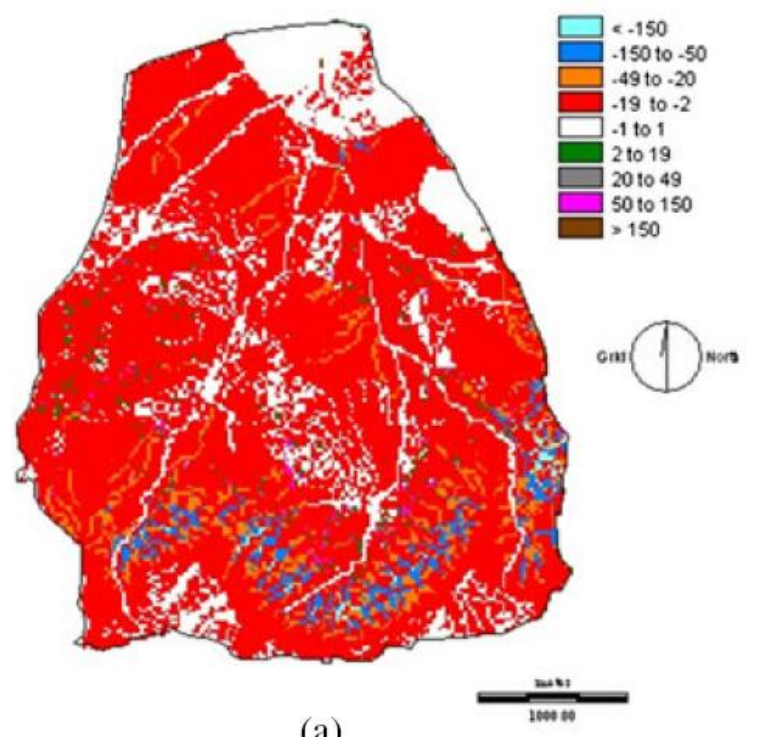

(a)

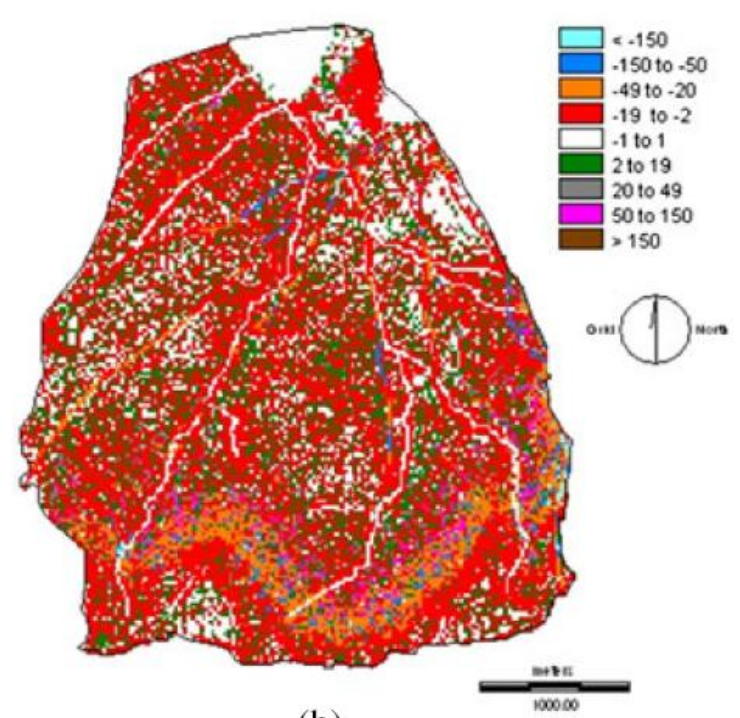

(b)

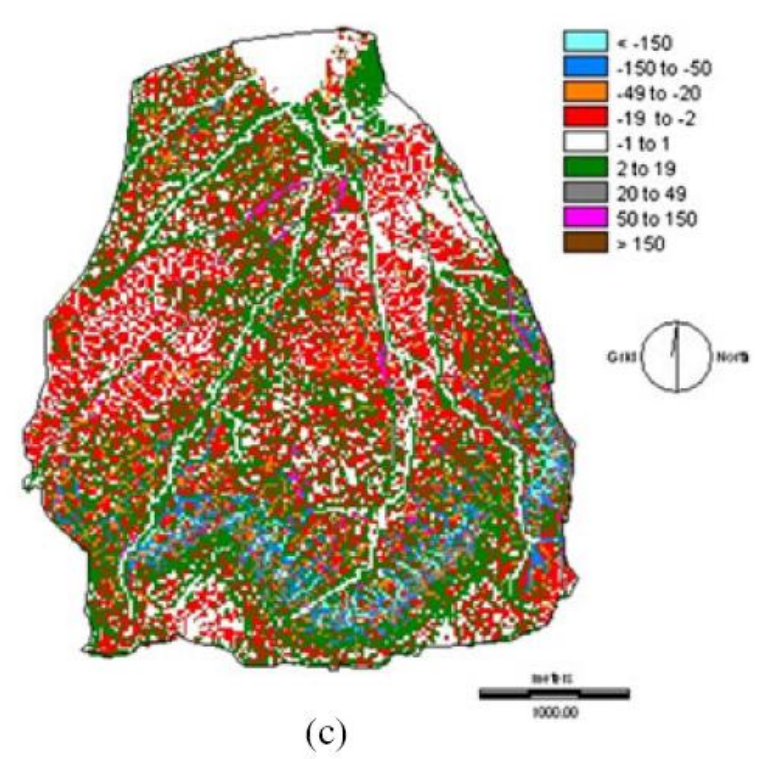


Table VII. A pair-wise comparison of absolute sediment yield and specific sediment yield predicted by the modified and the original WATEM/SEDEM

\begin{tabular}{|c|c|c|c|c|}
\hline \multirow[t]{2}{*}{ Pairs } & \multicolumn{2}{|c|}{ Mean difference } & \multicolumn{2}{|c|}{ Correlation } \\
\hline & & d.f. & $r$ & $n$ \\
\hline Modified PSY and original PSY & $555 \cdot 33^{\mathrm{a}}$ & 11 & $0.98^{*}$ & 12 \\
\hline Modified PSSY and original PSSY & $6 \cdot 42^{\mathrm{a}}$ & 11 & $0 \cdot 88^{*}$ & 12 \\
\hline
\end{tabular}

d.f., degree of freedom; $r$, correlation coefficient; $n$, number of samples; SY, sediment yield; SSY, specific sediment yield.

${ }^{a}$ n.s., non-significant.

*Significant at alpha 5 per cent level.

(ME $=0 \cdot 77$,Van Rompaey et al., 2001), river channels of the Murrumbidgee catchment in Australia $(M E=0.89$, Verstraeten et al., 2007); the impact of land use change and check-dams in Spain ( $M E$ of 0.84, Boix-Fayos et al., $2008)$ and for regional scale modelling of sediment delivery in Spain $(M E=0 \cdot 42-0 \cdot 82$, de Vente et al., 2008; $M E=0 \cdot 97$, Alatorre et al. 2010). Whereas the performance obtained in this study area is by far better than the performance reported for the Italian catchments located in various ecosystems $(M E=-0 \cdot 33$, Van Rompaey et al., 2005), for the hilly catchments of the Chinese Loess Plateau $(M E=-0 \cdot 32$, Feng et al. 2010).

It is clear that WATEM/SEDEM is still data demanding compared with most lumped regression models. Hence, the question arises if much benefit is to be gained from such a distributed model for which many input data have to be collected. Therefore this model was compared with regression equations (Eqs. 12 and 13) developed for predicting $S Y$ or $S S Y$ for the same study area by Haregeweyn et al. (2008):

$$
\begin{gathered}
S Y=690 T D L-0.58 S W C \quad\left(r^{2}=0.96 ; n=11\right) \\
S S Y=0.86 A v_{-} \text {slope }-0.269 S W C+10\left(r^{2}=0.80 ; n=11\right)
\end{gathered}
$$

Where: $S Y$ is the absolute sediment yield $\left(\mathrm{ty}^{-1}\right), S S Y$ is the specific sediment yield $\left(\mathrm{tha}^{-1} \mathrm{y}^{-1}\right), T D L$ is the total drainage length $(\mathrm{km}), A v \_$slope is the average catchment slope (per cent), $S W C$ is the fraction of catchment area treated with soil water conservation practices (per cent). These equations were established based on data of the 11 catchments that were also used for calibration of WATEM/ SEDEM (Table I), excluding Sewhimeda catchment.

When Eqs. 12 and 13 were applied for the 12 catchments used in this study; more accurate $S Y$ and $S S Y$ values were obtained as compared with the values obtained using both versions of the WATEM/SEDEM (Table VI). This might be explained by the insufficient representation of some erosion processes, especially gully erosion, in the case of WATEM/ SEDEM.

Its relative poor prediction was compared with the regression models however does not essentially rule out its usefulness for planning erosion and sediment yield because there are specific advantages of WATEM/SEDEM over that of the regression models, which can be summarised as follows: (i) modelling of the spatial pattern of soil erosion and sediment deposition so as to identify specific critical erosion source areas for catchment management; (ii) extraction of erosion-deposition rates based on land use, soils, slope and other spatial data layers of interest, which is useful for identifying its controlling factors (see Application of WATEM/SEDEM for assessment of spatial pattern, rate and hotspots of net erosion Section); and (3) evaluation of an integrated approach for catchment management (e.g. Verstraeten et al., 2002).

\section{Application of WATEM/SEDEM for Assessment of Spatial Pattern, Rate and Hotspots of Net Erosion}

A net erosion map $\left(\mathrm{tha}^{-1} \mathrm{y}^{-1}\right)$ was created for the Gindae catchment as an example by applying the modified version of WATEM/SEDEM, which was calibrated for the 12 catchments [Figure 10(a)] Net erosion is defined as the minimum value of erosion and transport capacity for each pixel.

As can be seen by comparing Figure 10(a) with Figure 11, sediment deposition occurs at the footslopes, while the maximum erosion rate occurred at the steepest slopes. For example, a maximum erosion rate of $150 \mathrm{tha}^{-1} \mathrm{y}^{-1}$ was observed at the steepest part of the catchment [slope $>50$ per cent; Figure 11(a)], which was covered with degraded bush-shrub land [Figure 11(b)] and with intercalated limestone-shale geological formation [Figure 11(c)]. On the other hand, erosion rates in the cultivated lands, which are rather located in the relatively gentle slope positions (slope $=0-5$ per cent) are much smaller.

Because of a lack of spatial observed data on soil loss within the studied catchments, evaluation of the accuracy of the spatial pattern of the model prediction was not possible. As an alternative, predicted soil loss and soil deposition rates were extracted for each land use type and compared with the findings of other similar studies conducted in the other parts of the country, which are all limited either to plot scale or field scale.

Table VIII shows extracted soil loss and sediment deposition rates per land use class for the 12 catchments. 


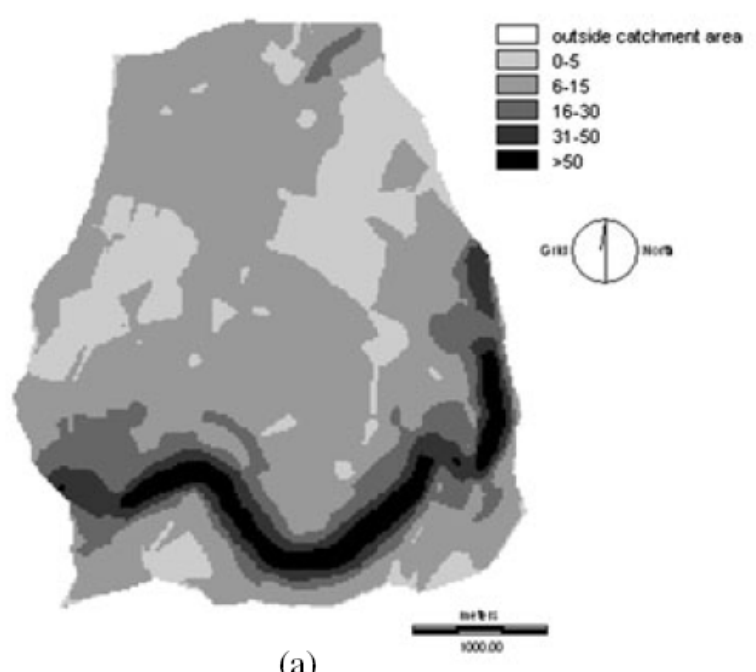

(a)

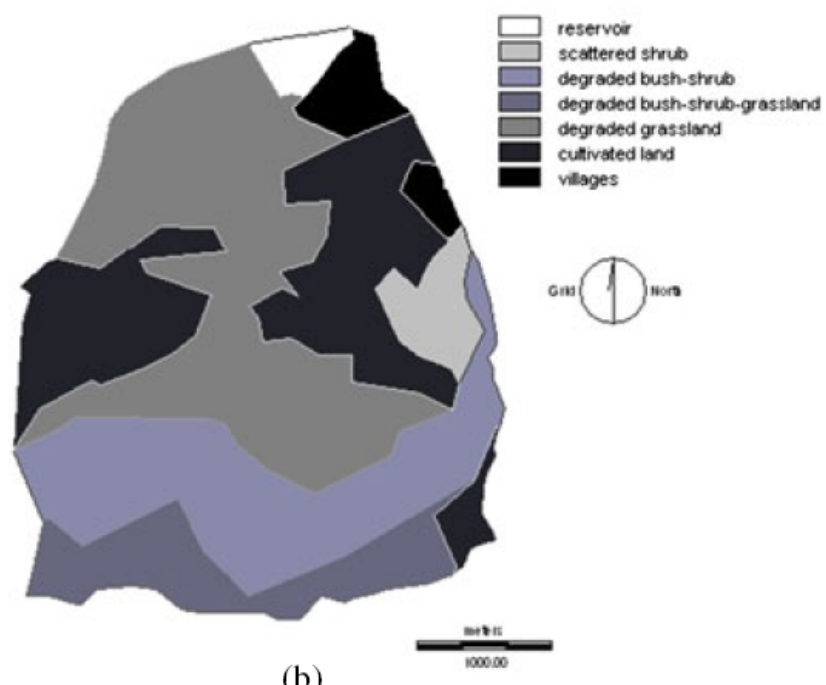

(b)

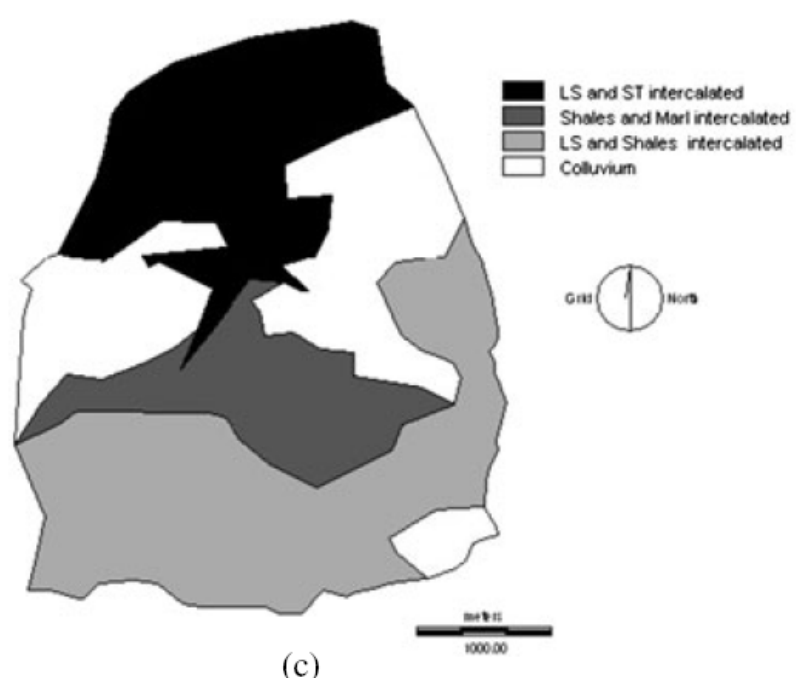

The result shows quite a large variation in soil loss rates not only across the different land use classes but also within the same land use both within a catchment and among catchments. Comparison based on average values at catchment level for the 12 catchments showed that both cultivated land and bush-shrub land show net erosion with a relatively high erosion rate for cultivated land $(10.8 \mathrm{t}$ $\left.\mathrm{ha}^{-1} \mathrm{y}^{-1}\right)$ compared with bush-shrub land $\left(2 \cdot 6 \mathrm{tha}^{-1} \mathrm{y}^{-1}\right)$. Although settlements act as sediment sink $\left(2.5 \mathrm{tha}^{-1} \mathrm{y}^{-1}\right)$, however, their areal extent is limited as compared with the other two land use classes. This indicates that soil erosion in the study area is not only controlled by the type of land use but also by other factors such as geology, topography and even with the degradation status of the specific land use. For example the characterization of bush-shrub lands as sediment source rather than as sediment sink in this study could be explained by the fact that this specific land use is in a state of degradation as evidenced in the field (Table I).

Soil loss rates for each land use type in this study (Table VIII) were compared with other studies conducted in Ethiopia. Hurni (1985) has documented soil loss data for various land uses at country level and reported average erosion from cropland $42 \mathrm{tha}^{-1} \mathrm{y}^{-1}$. However, those soil loss data were derived from plot data with no information on other factors controlling erosion rate such as topography, geology, soil type and human practices. A recent sediment budget study on May Zeg-Zeg catchment $\left(\mathrm{A}=2 \mathrm{~km}^{2}\right)$ in Tigray by Nyssen et al. (2009) reported an average sheet and rill soil loss rate of $9.9 \mathrm{tha}^{-1} \mathrm{y}^{-1}$ from cultivated land with limited catchment management practices, which is comparable with the findings of this study. This indicates the potential of WATEM/SEDEM for spatial analysis of soil erosion rates especially on sheet and rill erosion.

The predicted soil loss values in most parts of the catchment are generally high when compared with the soil formation rates in the region, which vary between 2 and $5 \mathrm{tha}^{-1} \mathrm{y}^{-1}$ (Hurni, 1983). This emphasises the importance of implementing appropriate $S W C$ measures critical erosion source areas prioritising the steepest part of the catchment [slope $>50$ per cent; Figure 11(a)], where a maximum erosion rate of $150 \mathrm{t} \mathrm{ha}^{-1} \mathrm{y}^{-1}$ and above was observed [Figure 11(b)]. Moreover, per catchment information on predicted source areas should be used rather than simple uniform application of $S W C$ measures over the entire catchment or land use classes.

Figure 11. Gindae catchment. Relating WATEM/SEDEM model's spatial net soil loss prediction $\left(\mathrm{tha}^{-1} \mathrm{y}^{-1}\right)$ [Figure 10(a)] with variation of catchment characteristics: [11(a)] slope (per cent), [11(b)] land use and [11(c)] lithology. LS, limestone; ST, sandstone. This figure is available in colour online at wileyonlinelibrary.com/journal/ldr 
Table VIII. Predicted average net soil loss rates $\left(\mathrm{tha}^{-1} \mathrm{y}^{-1}\right)$ by WATEM/SEDEM model for major land use classes for the 12 catchments in northern Ethiopia

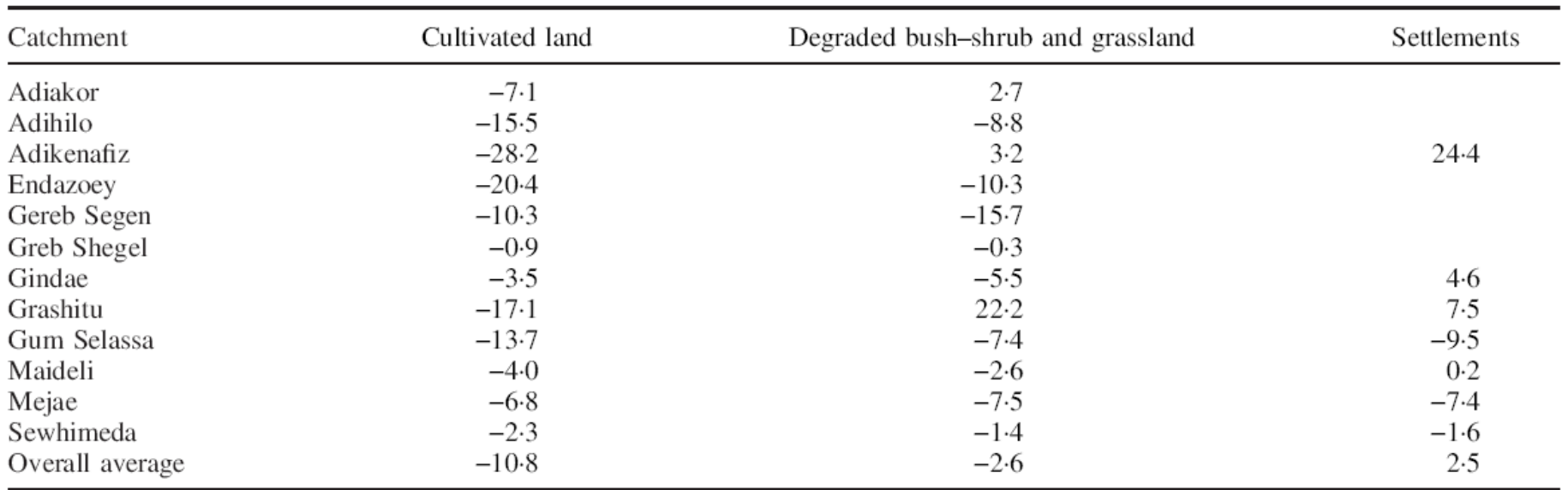

Negative values represent erosion, whereas positive values represent deposition.

\section{CONCLUSIONS}

The model efficiency of the WATEM/SEDEM was assessed on 12 catchments of northern Ethiopia using two different transport capacity equations where both were calibrated against cultivated land (KTC_arable). Calibration of the two versions of the sediment transport capacity yielded a reasonable estimate especially for $S Y$. The performance on both $S Y$ and $S S Y$ prediction was enhanced further when calibration procedure was applied for only nine catchments leaving out three catchments with significant active gully erosion. For these three gullied catchments, the model underestimated $S Y$ and $S S Y$. Even when very high $K T C$ values were used, the predicted total erosion is in the same order of magnitude as the measured sediment yield. The underestimation of erosion rates can be an indication for the significant contribution of gully erosion.

It was observed that the sediment transport equation proposed by Verstraeten et al. (2007) performed slightly better by few margins of $M E$ than the original version proposed by Van Rompaey et al. (2001) although the predicted mean sediment yield values were not significantly different (alpha 5 per cent). However, the model performance in both cases is quite comparable with the studies in central Belgium and in southeast Australia and better than its performance reported for Italian and Spanish catchments.

The predicted soil loss values in most parts of Gindae catchment are generally high as compared with the soil formation rates in the region. This emphasises the importance of implementing appropriate $S W C$ measures on critical erosion source areas prioritising the steepest part of the catchment (slope $>50$ per cent), where a maximum erosion rate of $150 \mathrm{tha}^{-1} \mathrm{y}^{-1}$ and more was observed. Moreover, per catchment information on predicted source areas should be used rather than simple uniform application of $S W C$ measures over the entire catchment or land use classes.
From a land management point of view, it is important to use a spatially distributed model such as WATEM/SEDEM (i) to predict absolute sediment yield and (ii) to assess the spatial distribution of erosion and identify critical erosion source areas for catchment management, more favourably in catchments with limited gully erosion.

What is lacking in the present versions of WATEM/ SEDEM is the gully and river channel erosion component. It is obvious that there are incising gullies that contribute significantly to sediment yield in addition to sheet and rill erosion. Further research is therefore needed to incorporate the contribution from gully erosion in the model structure.

\section{ACKNOWLEDGMENTS}

We thank the Flemish Inter University Council (VLIR) for the financial support of this study as part of the Zala Daget Project 'Fighting desertification in the Tigray Highlands: lessons to be learnt from successes and failures of soil erosion control techniques' and for a postdoc fellowship given to the senior author. The project research assistant Alemseged Gebregziabher and the driver Adam Haile are thanked for their assistance during the fieldwork. We also thank SAERT and REST offices for providing access to the technical reports on the dams and studied catchments. District authorities and farmers in the study area have facilitated our fieldwork as well. Finally, we would like to thank the two anonymous referees for providing very valuable comments on the earlier versions of this paper.

\section{REFERENCES}

Alatorre LC, Begueria S, Garcia-Ruiz JM. 2010. Regional scale modeling of hillslope sediment delivery: A case study in the Barasona Reservoir watershed (Spain) using WATEM/SEDEM. Journal of Hydrology 391: 109-123. 
Bard K, Coltorti M, Diblasi MC, Dramis F, Fattovich R. 2000. The environmental history of Tigray (northern Ethiopia) in the middle and late Holocene: A preliminary outline. African Archeological Review 17: 65-68.

Beasley DB, Huggins LF, Monke EJ. 1980. ANSWERS: a model for watershed planning. Transactions of ASAE 23: 938-944.

Boardman J. 1995. Damage to property by runoff from agricultural land, south downs, southern England, 1976-93. The Geographical Journal 161: 177-191

Boix-Fayos C, de Vente J, Martínez-Mena M, Barberá GG, Castillo V. 2008. The impact of land use change and check-dams on catchment sediment yield. Hydrological Processes 22: 4922-4935.

CSA. 2001. Statistical abstract 2000. Federal Democratic Republic of Ethiopia, Central Statistical Authority: Addis Ababa; 403

Declercq F, Poesen J. 1991. Erosiekarakteristieken van de bodem in Laag-en Midden-Belgium. Tijdschrift van de Belgische Vereniging voor Aardrijkskundige Studies BEVAS 1: 29-46.

Desmet PJJ, Govers G. 1995. GIS-based simulation of erosion and deposition patterns in an agricultural landscape: A comparison of model results with soil map information. Catena 25: 389-401.

Desmet PJJ, Govers G. 1996a. A GIS-procedure for the automated calculation of the USLE LS-factor on topographically complex landscape units. Journal of Soil Water Conservation 51: 427-433.

Desmet PJJ, Govers G. 1996b. Comparison of routing algorithms for digital terrain models and their implications for predicting ephemeral gullies. International Journal of Geographic Information Science 10: 311-331.

Desmet PJJ, Govers G. 1997. Two-dimensional modeling of the withinfield variation in rill and gully geometry and location related to topography. Catena 29: 283-306.

FAO. 2004. http://www.fao.org/giews/english/basedocs/eth/ethpople.stm. [Accessed 20 January 2004].

FAO. 2008. Standardizing land cover mapping for tsetse and trypanosomiasis decision making. Annex 1: land cover for $T \& T$ decision-making: standard description. PAAT Scientific and Technical Series 8; 93.

Feng X, Wang Y, Chen L, Fu B, Bai G. 2010. Modeling soil erosion and its response to land-use change in hilly catchments of the Chinese Loess Plateau. Geomorphology 118: 239-248.

Gebremichael D, Nyssen J, Poesen J, Deckers J, Haile M, Govers G, Moeyersons J. 2005. Effectiveness of stone bunds on controlling soil erosion on cropland in the Tigray highlands, Northern Ethiopia. Soil Use and Management 21: 287-297.

Gee GW, Bauder JW. 1982. Particle size analysis. In Method of Soil Analysis: Part 1, Physical and Mineralogical Methods. ASA Monograph Number 9, Klute A (ed). ASA: Madison, WI; 383-411.

Gete Z. 1999. Application and adaptation of WEPP to the traditional farming system of the Ethiopian highlands. Paper presented at the Conference of the International Soil Conservation Organization, Lafayette, IN, 24-28 May 1999.

Govers G, Poesen J. 1988. Assessment of the interrill and rill contributions to total soil loss from an upland field plot. Geomorphology 1: 343-354.

Haregeweyn N, Yohannes F. 2003. Testing and Evaluation of Agricultural Nonpoint Source Pollution Model (AGNPS) on Agucho Catchment, Westem Harerghie. Agriculture, Ecosystems \& Environment 99: 201-212.

Haregeweyn N, Poesen J, Nyssen J, Verstraeten G, de Vente J, Deckers J, Moeyersons J. 2005. Specific sediment yield in Tigray-Northern Ethiopia: Assessment and semi-quantitative modelling. Geomorphology 69: 315-331.

Haregeweyn N. 2006. Reservoir sedimentation in the North Ethiopian Highlands: assessment and modelling of controlling factors and impacts. $\mathrm{PhD}$ Thesis, Katholieke Universiteit Leuven, Department of Geography and Geology, Heverlee; 243. ISBN: 90-8649-017-4

Haregeweyn N, Poesen J, Nyssen J, De Wit J, Haile M, Govers G, Deckers J. 2006. Reservoirs in Tigray: Characteristics and sediment deposition problems. Land Degradation \& Development 17: 211-230.

Haregeweyn N, Poesen J, Nyssen J, Govers G, Verstraeten G, De Vente J, Deckers J, Moeyersons J, Haile M. 2008. Sediment yield variability Northern Ethiopia: A quantitative analysis of its controlling factors. Catena 75: 65-76.

Hengsdijk H, Meijerink GW, Mosugu ME. 2005. Modelling the effect of three soil and water conservation practices in Tigray, Ethiopia. Agriculture, Ecosystems \& Environment 105: 29-40.
Hurni H. 1979. Semien-Äthiopien: methoden zur Erfassung derBodenerosion. Geomethodica 4: 151-182.

Hurni H. 1983. Soil formation rates in Ethiopia. Working paper No. 2, FAO/Ministry of Agriculture. Joint Project EHRS, Addis Ababa.

Hurni H. 1985. Soil Conservation Manual for Ethiopia: A Field Manual for Conservation Implementation. Soil Conservation Research Project: Addis Ababa.

Hurni H. 1989. Late Quaternary of Simen and other mountains in Ethiopia. In Quaternary and Environmental Research on East African Mountains, Mahaney W (ed). Balkema: Rotterdam; 105-120.

Hussen M, Yohannes F, Zeleke G. 2004. Validation of Agricultural NonPoint source (AGNPS) pollution model in Kori catchment, South Wollo, Ethiopia. International Journal of Applied Earth Observation and Geoinformation 6: 97-109.

Jetten V, Govers G, Hessel R. 2003. Erosion models: quality of spatia predictions. Hydrological Processes 17: 887-900.

Krauer J. 1988. Rainfall, erosivity and isoerodent map of Ethiopia. Soil Conservation Research Project, Research Report 15. University of Berne, Switzerland, 132

McCool DK, Foster GR, Mutchler CK, Meyer LD. 1989. Revised slope length factor for the universal soil loss equation. Transactions of the ASAE 32: $1571-1576$.

McDowell RW, Srinivasan MS. 2009. Indentifying critical source areas for water quality: 2 . Validating the approach for phosphorous and sediment losses in grazed headwater catchments. Journal of Hydrology 379: 68-80.

Merritt WS, Letcher RA, Jakeman AJ. 2003. A review of erosion and sediment transport models. Environmental Modeling and Software 18: 761-799.

Munro RN, Deckers J, Grove AT, Mitiku Haile, Poesen J, Nyssen J. 2008 Soil and erosion features of the Central Plateau region of Tigrai - Learning from photo monitoring with 30 years interval. Catena 75: 55-64.

Nash JE, Sutcliffe JV. 1970. River flow forecasting through conceptual models: Part 1: A discussion of principles. Journal of Hydrology 10: 282-290.

Nearing MA. 1997. A single, continuous function for slope steepness influence on soil loss. Soil Science Society of America Journal 61: 917-919.

Nyssen J, Poesen J, Moeyersons J, Deckers J, Mitiku Haile, Lang A. 2004 Human impact on the environment in the Ethiopian and Eritrean highlands-a state of the art. Earth Science Reviews 64: 273-320.

Nyssen J, Vandenreyken H, Poesen J, Moeyersons J, Deckers J, Mitiku Haile, Salles C, Govers G. 2005. Rainfall erosivity and variability in the Northern Ethiopian Highlands. Journal of Hydrology 311: 172-187.

Nyssen J, Haregeweyn N, Descheemaeker K, Gebremichael D, Vancampenhout K, Poesen J, Haile M, Moeyersons J, Buytaert W, Naudts J, Deckers S, Govers G. 2006a. Comment on 'Modeling the effect of soil and water conservation practices in Tigray, Ethiopia'. Agriculture, Ecosystems \& Environment 106: 407-411.

Nyssen J, Poesen J, Veyret-Picot M, Moeyersons J, Mitiku Haile, Deckers J, De wit J, Naudts J, Kassa Teka, Govers G. 2006b. Assessment of gully erosion rates through interviews and measurements: a case study from Northern Ethiopia. Earth Surface Processes and Landforms 31: 167-185. DOI: 10.1002/esp.1317.

Nyssen J, Clymans W, Poesen J, Vandecasteele I, De Baets S, Haregeweyn N, Naudts J, Hadera A, Moeyersons J, Haile M, Deckers J. 2009. How integrated catchment management and reduced grazing affect the sediment budget - a comprehensive study in the north Ethiopian highlands. Earth Surface Processes and Landforms 34: 1216-1233.

Nyssen J, Clymans W, Descheemaeker K, Poesen J, Vandecasteele I, Vanmaercke M, Zenebe A, Van Camp M, Haile M, Haregeweyn N, Moeyersons J, Martens K, Gebreyohannes T, Deckers J, Walraevens K 2010. Impact of Soil and Water Conservation on Catchment Hydrological Response - a Case in North Ethiopia. Hydrological Processes 24: 1880-1895.

Poesen JW, Torri D, Bunte K. 1994. Effects of rock fragments on soil erosion by water at different spatial scales: A review. Catena 23: 141-166.

Prosser IP, Rustomji P. 2000. Sediment transport capacity relations for overland flow. Progress in Physical Geography 24: 179-193.

Renard KG, Foster GR, Weesies GA, McCool DK, Yoder DC. 1997. Predicting soil erosion by water: A guide to conservation planning with the revised universal soil loss equation (RUSLE). Agriculture Handbook, vol. 703. US Department of Agriculture: Washington DC; 384. 
TFAP. 1996. Tigray Bureau of Agriculture and Natural Resources Development. Tigray Forest Action Programme, Mekelle, Ethiopia; 122.

Van de Sype P. 2005. Impacts of small-scale mining on erosion and sediment yield in small catchments in the northern Ethiopian highlands. MSc Thesis. Katholieke Universiteit Leuven, Department GeographyGeology, Heverlee; 296.

Van Oost k, Govers G, Cerdan O, Thaure D, Van Rompaey A, Steegen A, Nachtergaele J, Takken I, Poesen J. 2005. Spatially distributed data for erosion model calibration and validation: The Ganspoel and Kinderveld datasets. Catena 61: 105-121.

Van Oost K, Govers G, Desmet PJJ. 2000. Evaluating the effects of landscape structure on soil erosion by water and tillage. Landscape Ecology 15: 579-591.

Van Rompaey AJJ, Verstraeten G, Van Oost K, Govers G, Poesen J. 2001. Modelling mean annual sediment yield using a distributed approach. Earth Surface Process Landforms 26: 1221-1236. DOI: 10.1002/esp.275.

Van Rompaey AJJ, Krasa J, Dostal T, Govers G. 2003. Modelling sediment supply to rivers and reservoirs in Eastern Europe during and after the collectivisation period. Hydrobiologia 494: 169-176.

Van Rompaey AJJ, Bazzoffi P, Jones RJA, Montanarella L. 2005. Modeling sediment yields in Italian catchments. Geomorphology 65: 157-169, de Vente J, Poesen J. 2005. Predicting soil erosion and sediment yield at the basin scale: Scale issues and semi-quantitative models. Earth Science Reviews 71: 95-125.

de Vente J, Poesen J, Verstraeten G, Van Rompaey A, Govers G. 2008. Spatially distributed modelling of soil erosion and sediment yield at regional scales in Spain. Global and Planetary Change 60: 393-415.

Verstraeten G, Poesen J. 2000. Estimating trap efficiency of small reservoirs and ponds: Methods and implications for the assessment of sediment yield. Progress in Physical Geography 24: 219-251.

Verstraeten G, Van Oost K, Van Rompaey AJJ, Poesen J, Govers G. 2002. Evaluating an integrated approach to catchment management to reduce soil loss and sediment pollution through modeling. Soil Use and Management 19: 386-394.

Verstraeten G, Prosser I, Fogarty P. 2007. Predicting the spatial patterns of hillslope sediment delivery to river channels in the Murrumbidgee catchment, Australia. Journal of Hydrology 334: 440-454.

Virgo KJ, Munro RN. 1978. Soil and erosion features of the central pleatux of Tigray, Ethiopia. Geoderma 20: 131-157.

Wischmeier WH, Smith DD. 1978. Predicting rainfall erosion losses: A guide to conservation planning. Agriculture Handbook, vol. 537. United States Department of Agriculture: Washington, DC; 58. 